\title{
Redescription of Odontostilbe pulchra (Gill, 1858) (Teleostei: Characidae: Cheirodontinae), and description of two new species from the río Orinoco basin
}

\author{
Cristina M. Bührnheim*, ** and Luiz R. Malabarba*, ***
}

Odontostilbe pulchra, previously considered species inquirenda in Cheirodontinae and doubtfully assigned from the río Orinoco basin, is redescribed with the rediscovery of two syntypes. Originally described to the Island of Trinidad, O. pulchra is widespread in Venezuela, the río Orinoco basin, in smaller coastal drainages of northern South America, in the Lake Valencia system, and río Essequibo basin. A punctual occurrence in the upper rio Negro, near southernmost headwaters of the río Orinoco, extends its distribution to the Amazon basin. Additionally, two new species of Odontostilbe from the río Orinoco basin are described.

Odontostilbe pulchra, anteriormente considerada como species inquirenda em Cheirodontinae e registrada com dúvidas para a bacia do río Orinoco, é redescrita com a redescoberta de dois síntipos. Descrita originalmente para a ilha de Trinidad, $O$. pulchra apresenta-se largamente distribuída na Venezuela, incluindo a bacia do río Orinoco, pequenas bacias costeiras do norte da América do Sul, no sistema do lago Valencia e bacia do río Essequibo. Uma ocorrência pontual na região superior do rio Negro, próximo às cabeceiras do río Orinoco, estende sua distribuição para a bacia Amazônica. Adicionalmente, são descritas duas novas espécies de Odontostilbe da bacia do Orinoco.

Key words: Northern South America, Syntypes, Taxonomy, Poecilurichthys pulcher.

\section{Introduction}

Odontostilbe Cope, 1870 belongs to the subfamily Cheirodontinae, a recognized monophyletic clade of Characidae including about 15 genera and 50 species of small Neotropical fishes (Malabarba, 1998, 2003; Malabarba et al., 2004; Bührnheim \& Malabarba, 2006). A total of ten species were recognized in Odontostilbe by Bührnheim \& Malabarba (2006): O. pulchra (Gill, 1858), O. fugitiva Cope, 1870, O. pequira (Steindachner, 1882), O. paraguayensis Eigenmann \& Kennedy, 1903, O. microcephala Eigenmann, 1907, O. dierythrura Fowler, 1940, O. euspilura (Géry, 1972), O. ecuadorensis Bührnheim \& Malabarba, 2006, O. nareuda Bührnheim \& Malabarba, 2006, and O. parecis Bührnheim \& Malabarba, 2006 , but the genus contains at least seven other undescribed species.

A single species of Odontostilbe has been so far assigned to the río Orinoco basin. Odontostilbe pulchra was originally described from the Island of Trinidad as Poecilurichthys pulcher Gill, 1858. The genus Poecilurichthys Gill, 1858 was described in that same study and Poecilurichthys brevoortii Gill, 1858 [= Astyanax bimaculatus (Linnaeus, 1758)] was posteriorly designated as the type species of that genus by Eigenmann (1910: 432). Therefore, Poecilurichthys was considered a junior synonym or a subgenus of Astyanax Baird \& Girard, 1854. Lütken (1875) redescribed Odontostilbe pulchra as Chirodon (Odontostilbe) pulcher. After that, practically all cheirodontine material from the río Orinoco and Trinidad have been referred in the literature as Cheirodon pulcher, Odontostilbe pulcher or Odontostilbe pulchra, but these references seems to include more than one species of Odontostilbe, as well as undescribed species of Odontostilbe, Holoshesthes and Serrapinnus.

The poor and not diagnostic original description of Odontostilbe pulchra, combined with the use of this specific name for several cheirodontine species, led Malabarba (2003)

\footnotetext{
*Museu de Ciências e Tecnologia, PUCRS, Av. Ipiranga, 6681, P. O. Box. 1429, 90619-900, Porto Alegre, RS, Brazil.

**Universidade Federal do Amazonas, ICB, Departamento de Biologia, Lab. Zoologia, Av. Gen. Rodrigo Otávio Jordão Ramos, 3000 , 69077-000, Manaus, AM, Brazil. cmbuhrn@yahoo.com.br

***Universidade Federal do Rio Grande do Sul, IB, Departamento de Zoologia, Av. Bento Gonçalves, 9500, bloco IV, prédio 43435, 90540 000, Porto Alegre, RS, Brazil.malabarb@ufrgs.br
} 
to consider "Poecilurichthys pulcher" Gill, 1858 as species inquirenda. In this paper we redescribe " $P$. pulcher" based on the rediscovery of two syntypes, and review its distribution in Trinidad and in northern South American drainages. In adittion, two new Odontostilbe species sympatric with $O$. pulchra in the río Orinoco basin are described.

\section{Material and Methods}

Counts and measurements follow Fink \& Weitzman (1974) and were made primarily on the left side of the specimens. Head length is the distance between the tip of the snout and the posterior end of the subopercle, which is slightly posterior to the margin of the opercle. Total vertebrae number includes the four vertebrae of the Webberian apparatus, and the terminal "half centrum" according to Malabarba \& Weitzman (1999). The gill raker at the junction of the ceratobranchial and the epibranchial is referred as the posteriormost gill raker of the lower branch of the first branchial arch, and counted jointly with the gill rakers of the lower branch as in Bührnheim \& Malabarba (2006). Specimens were cleared and stained according to Taylor \& Van Dyke (1985) and together with radiographs were used for counting vertebrae, teeth, and gill rakers. Scanning electron micrographs (SEM) were obtained from teeth and denticulation of gill rakers. Values of the holotypes of the new species and of the two syntypes of Odontostilbe pulchra are marked in bold in the descriptions. Males and females are recognized only when specimens are dissected, or when they show sexual dimorphism in specimens of similar size in the same collecting lot, otherwise they were termed as unsexed (Bührnheim \& Malabarba, 2006). The two syntypes of Odontostilbe pulchra recognized as females are an exception to this rule, because principal component analysis and regression analyses grouped them with females.

The following institutions provided material for the study: ANSP - Academy of Natural Sciences, Philadelphia, USA; CAS - California Academy of Sciences, San Francisco, USA; FMNH - Field Museum of Natural History, Chicago, USA; INHS - Illinois Natural History Survey, Champaign, USA; ICNMNH Universidad Nacional de Colombia, Museu de Historia Natural, Bogotá, Colombia; INPA - Instituto Nacional de Pesquisas da Amazônia, Manaus, Brazil; MBUCV - Museo de Biología, Universidad Central de Venezuela, Caracas, Venezuela; MCP Museu de Ciências e Tecnologia, Porto Alegre, Brazil; MCNG Museo de Ciencias Naturales de Guanare, Guanare, Venezuela; MHNG - Muséum d'Histoire Naturelle, Geneva, Switzerland, MNHN - Muséum d'Historie Naturelle, Paris, France; MZUSP - Museu de Zoologia da Universidade de São Paulo, São Paulo, Brazil; ROM - Royal Ontario Museum, Toronto, Canada; UMMZ - University of Michigan Museum of Zoology, Ann Arbor, USA; USNM - National Museum of Natural History, Washington D.C., USA. Abbreviations given after the number of specimens in each lot are as follows: $\mathrm{m}$ - morphometrics and meristics taken; c- only meristics taken; $\mathrm{x}$ - meristics taken from x-rays; c\&scleared and stained specimens.
Statistical analyses. Principal component analysis (PCA) was used to check overall variation among samples, including differences in morphometrics among species or between sexes, being an input to multiple regressions (Johnson \& Wichern, 1998). PCA on covariances of logarithmically transformed measurements were obtained using Past version 1.28 2004, and Sigma Plot version 6.102000 . The first principal component was partitioned out, considering that it mostly accounts for size variation (Strauss, 1985). Multiple linear regressions were applied to describe morphometric differences among species or between sexes.

\section{Results}

\section{Odontostilbe pulchra (Gill, 1858)}

Fig. 1

Poecilurichthys pulcher Gill, 1858: 419 [original description, type locality: western portion of the Island of Trinidad].

Tetragonopterus pulcher. -Günther, 1864: 317 [new generic combination].

Chirodon (Odontostilbe) pulcher. -Lütken, 1875: 236-238 [new generic combination, redescription].

Odontostilbe pulcher. -Eigenmann \& Eigenmann, 1892: 54 [new generic combination]. -Eigenmann, 1909: 327 [listed, Trinidad]. -Eigenmann, 1910: 429 [listed, Trinidad]. -Price, 1955: 11, Fig. 3 [map with distribution in the Caroni, Caparo, and northern Oropouche drainages in Trinidad, known to occur in Venezuela]. -Boeseman, 1960: 72, 88-89 [listed, synonym list]. -Eigenmann, 1920: 4, 9-10 [listed to the Valencia basin, Venezuela, Maracay, Rio Bue]. -Schultz, 1944: 318319 [list of synonyms, specimen from Caripito, Venezuela]. Cheirodon pulcher. -Ulrey, 1895: 289-290 [in key, including teeth counts, Trinidad].

Chirodon pulcher. -Regan, 1906: 378, 380, 385, Pl. XXII. Fig. 2 [species redescription, distribution Trinidad, Cumuto, partial designation in key, illustration]. -Guppy, 1934: 118, $120-122$, Fig. 5 [recorded in ponds and water holes in the vicinity of rice fields, compilation of Regan's 1906 drawing, listed as larvicidal fish, usually in dams, only from Trinidad].

Odontostilbe pulchra. -Eigenmann, 1915: 90, 95-96, Pl. XVII. Fig. 1 [in key, Regan's characters compilation, reproduction of Regan's illustration]. -Fowler, 1943: 65-66. Fig. 2 [common name sardine doree, drawing of a specimen]. Böhlke, 1954: 137-140 [possibly synonym of Odontostilbe fugitiva, table with measurements and counts of $O$. pulchra and O. fugitiva]. -Géry, 1977: 558 [in key].

Syntypes. MNHN 0000-9593, 2 (females $28.7 \mathrm{~mm}$ SL and 30.8mm SL), western portion of Trinidad.

Non-type material. Uncertain drainage, TRINIDAD: CAS 70933, 1 (male $24.7 \mathrm{~mm} \mathrm{SL}$ ), $10^{\circ} 37^{\prime} \mathrm{N} 61^{\circ} 13^{\prime} \mathrm{W}$. Cunapo River basin, TRINIDAD: INHS 40081, 4m (2 females 32.6-33.3 mm SL, 2 unsexed 26.3-29.9mm SL), Quare River, $1 \mathrm{~km}$ E Valencia on road to Arima. 


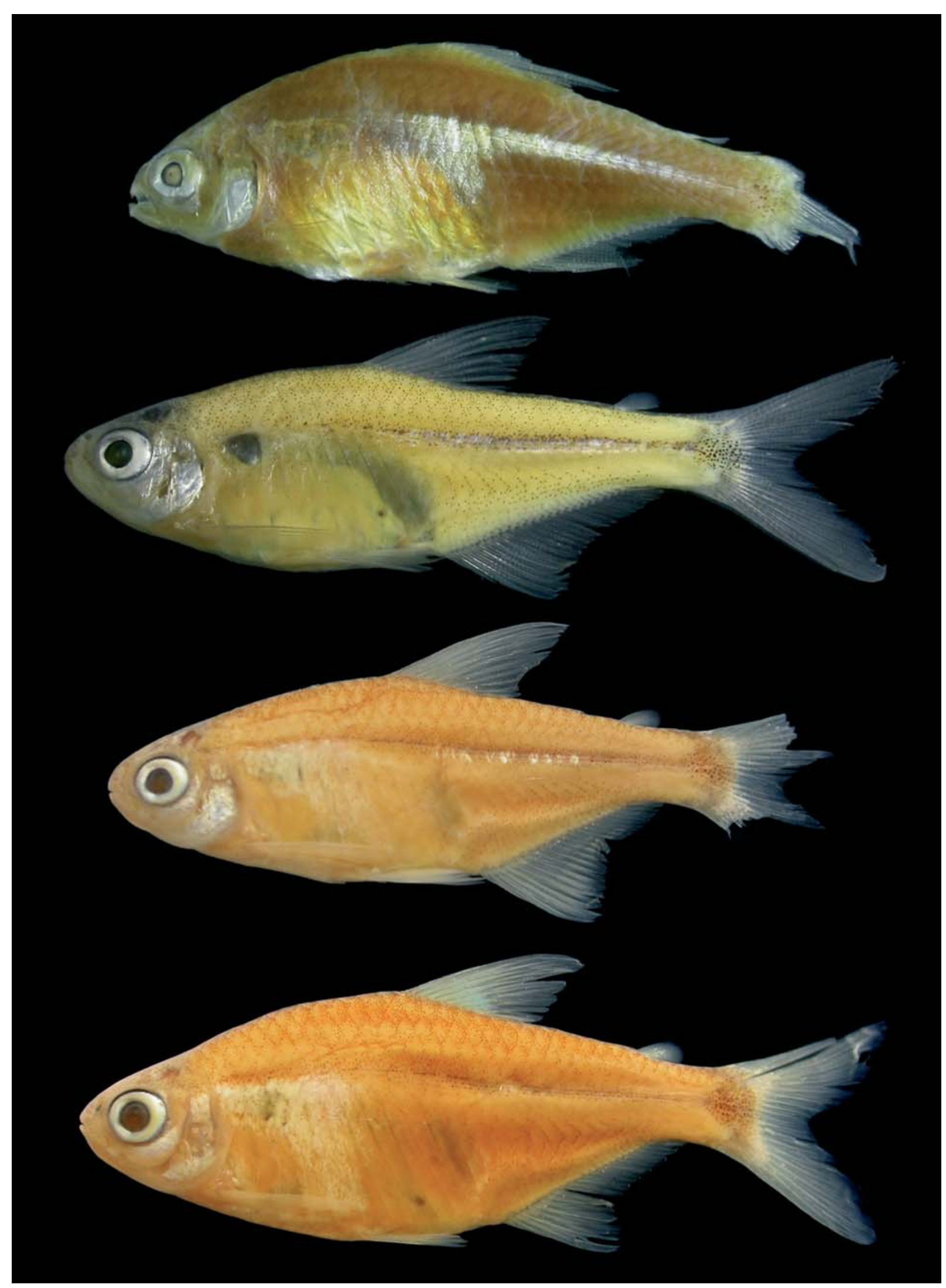

Fig. 1. Odontostilbe pulchra, syntype MNHN 0000-9593, female $28.7 \mathrm{~mm}$ SL (top), a specimen INHS 40101, male $32.3 \mathrm{~mm}$ SL from Trinidad (middle top), and specimens MCP 38863, male $28.6 \mathrm{~mm} \mathrm{SL}$ (middle bottom), and female $32.5 \mathrm{~mm}$ SL (bottom) from río Orinoco basin. 
Caroni River basin, TRINIDAD: ANSP 70181, 1 (unsexed 18.2 $\mathrm{mm}$ SL), sent from Port-of-Spain. INHS 40101, 20m (13 males 29.4$32.7 \mathrm{~mm}$ SL, 1 male $32.5 \mathrm{~mm}$ SL c\&s, 4 females 33.6-34.6 mm SL, 1 female $34.4 \mathrm{~mm}$ SL c\&s, and 1 unsexed $25.1 \mathrm{~mm} \mathrm{SL}$ ), Cumuto River, $5 \mathrm{~km} \mathrm{~S}$ Brazil on the road to Talparo. ROM 41035, 9 unsexed 17.9$27.6 \mathrm{~mm}$, east side of north-south canal south of Blue river, Caroni swamp. ROM 44764, 20m (6 males 26.2-28.6 mmSL, 11 females 28.4-36.9 mm SL, 3 unsexed 28.3-31.2 mm SL), near Bamboo Grove on Churchill and Roosevelt highway, St. Joseph River. ROM 1082, 2 c\&s (1 male, 1 unsexed), near Bamboo Grove on Churchill and Roosevelt highway, St. Joseph River. ROM 1139CS, 1 c\&s, near Bamboo Grove on Churchill and Roosevelt highway, St. Joseph River. USNM 290410, 7 unsexed 30.8-37.2 mm SL, Valencia River, [Aripo River drainage, upper Caroni River basin]. USNM 177552, 50 (2c of 10 females 27.1-36.3 mm SL, 11 males 26.6-32.1 mm SL, 6 unsexed 14.6-18.2 mm SL), [Caroni County], Piarco. O'Meara River basin, TRINIDAD: ROM 41069, $1 \mathrm{~m}$ (female $35.0 \mathrm{~mm} \mathrm{SL}$ ), small stream, 13 miles east of Port Spain on Churchill-Roosevelt highway, at B1$13,10^{\circ} 38^{\prime} \mathrm{N} 61^{\circ} 20^{\prime} \mathrm{W}$. Bejucal River basin, TRINIDAD: UMMZ 189000, 20 of 40 (20 unsexed 18.5-29.2 mm SL), [Caroni County, Cunupia], Mt. Plaisance Village, BWI. Tuy River basin - Caribbean coastal drainage, VENEZUELA: INHS 29318, 16 (3 males 24.8$27.0 \mathrm{~mm} \mathrm{SL}, 1 \mathrm{male} 28.9 \mathrm{~mm} \mathrm{SL}, 12$ unsexed 12.5-32.0 mm SL), Miranda, Quebrada Querepe, tributary of río Merecure, $5 \mathrm{~km} \mathrm{NE}$ Caucagua. Río Unare basin - Caribbean coastal drainage, VENEZUELA: ANSP 165594, 2 (unsexed 18.9-21.8 mm SL) alizarin stained, [Anzoategui], Laguna at San Pable, L. Encantada. INHS 31295, 5 (1 male $34.0 \mathrm{~mm}$ SL, 4 unsexed 20.5-22.9 mm SL), Guarico, quebrada Honda, río Unare, $7 \mathrm{~km}$ W Zaraza, hwy. 13. Lake Valencia basin, VENEZUELA: CAS 70934, 43 (19 males 28.5-31.3 mm SL, 9 females 31.5-36.4 mm SL, 15 unsexed 24.7-37.9 mm SL), Aragua, [río Bue], Maracay. MCP 14945, 9 (1 male $29.8 \mathrm{~mm}$ SL, 8 unsexed 25.1$34.5 \mathrm{~mm} \mathrm{SL}$ ), caño Cambur tributary to Lake Valencia, $11 \mathrm{~km} \mathrm{~S}$ El Valencia, formerly ANSP 150108. INHS 60011, 6 (1 male $29.2 \mathrm{~mm}$ SL, 5 unsexed 24.4-29.3 mm SL), Carabobo, río Las Penitas, Vigirima, $10^{\circ} 20^{\prime} \mathrm{N} 67^{\circ} 52^{\prime} \mathrm{W}$. Río Meta basin, COLOMBIA, META: ANSP 128231, 10 of 41 (7 males 24.6-28.9 mm SL, 3 females 29.5-30.5 $\mathrm{mm} \mathrm{SL}$ ), río Metica ca. $3 \mathrm{~km} \mathrm{SE}$ Mozambique ranch, $03^{\circ} 57^{\prime} \mathrm{N}$ $73^{\circ} 02^{\prime} \mathrm{W}$. ANSP 131976, 21 (5 males 26.4-31.6 mm SL, 16 unsexed 25.1-37.7 mm SL), río Metica, ca. $1.5 \mathrm{~km}$ E of Rajote. ANSP 131977, 10 (2 males 25.5-31.3 mm SL, 8 unsexed 25.1-32.6 mm SL), same locality as ANSP 131976. ANSP 133239, 2 (unsexed 28.0-32.1 mm SL), caño Rico at Brasília. ANSP 139335, 8 (unsexed 25.1-35.6 mm SL), same locality as ANSP 128231. ANSP 139346, 10x of 15 (6 males 21.2-30.8 mm SL, 2 females 32.0-30.1 mm SL, 7 unsexed 25.3$31.5 \mathrm{~mm} \mathrm{SL}$ ), same locality as ANSP 128231. ANSP 139347, 1 (female $29.6 \mathrm{~mm} \mathrm{SL}$ ), tributary of caño El Chocho $c a .5 \mathrm{~km} \mathrm{~N}$ of La Siberia. ANSP 139348, 10 (2 males $23.1 \mathrm{~mm} \mathrm{SL} \mathrm{\&} 25.0 \mathrm{~mm} \mathrm{SL}, 8$ unsexed 24.4-29.5 mm SL), tributary of caño La Raya, $1^{\text {st }}$ caño $\mathrm{N}$ of La Siberia. ANSP 139349, 3 (females 29.1-33.5 mm SL), laguna El Batin, $c a .4 \mathrm{~km} \mathrm{SW}$ upstream of lake Mozambique, S side of río Metica. ANSP 139450,8 of 21 (4 males $24.2-25.9 \mathrm{~mm} \mathrm{SL}, 4$ females 25.7-27.5 mm SL), MCP 40990 (1 male $24.3 \mathrm{~mm}$ SL c\&s, 1 female $26.9 \mathrm{~mm}$ SL c\&s), laguna Doctor Sanchez, a cut-off oxbow, entrance ca. $5 \mathrm{~km} \mathrm{SW}$ from inlet to lake Mozambique, $03^{\circ} 56^{\prime} \mathrm{N} 73^{\circ} 08^{\prime} \mathrm{W}$. ANSP 139452, 2 (1 male $25.4 \mathrm{~mm} \mathrm{SL}, 1$ female $25.5 \mathrm{~mm} \mathrm{SL}$ ), río Negro, downstream from main Villavicencio-Puerto Lopez highway at La Balsa, W side of river. ANSP 139456, 1 (female $33.8 \mathrm{~mm} \mathrm{SL}$ ), río Negrito at bridge on road joining Puerto Lopez and Villavicencio, 200-400 yd downstream of bridge. ANSP 139469, 4 (2 males 24.2$27.3 \mathrm{~mm} \mathrm{SL}, 2$ females $27.1-27.6 \mathrm{~mm} \mathrm{SL}$ ), same locality as ANSP 139349. ANSP 139471, 23 of 63 (11 males 23.1-27.4 mm SL, 12 females 28.4-32.6mm SL), caño Rico at La Defensa, NW of Laguna Mozambique, becomes caño Buenaventura before entering río Negro. ANSP 139472, 94m (4 males 23.0-25.0 mm SL, 4 females 27.2-34.7 $\mathrm{mm} \mathrm{SL}$ ), tributary of La Raya, $1^{\text {st }}$ caño north of La Siberia, $04^{\circ} 50^{\prime} \mathrm{N}$ $73^{\circ} 05^{\prime} \mathrm{W}$. ANSP 139485, 74 (14 males 18.9-23.6 mm SL, 60 unsexed 18.3-24.3 mm SL), Mozambique ranch, lake Mozambique, N shore at main house. ANSP 139572, 3x of 128 (68 males 20.9-31.1 mm SL,
60 unsexed 24.5-33.9 mm SL), río Negrito at bridge at La Balsa. ANSP $139579,20 \mathrm{~m}$ of 199 (10 males 16.6-25.7 mm SL, 10 females 23.1$29.2 \mathrm{~mm} \mathrm{SL}$ ), Mozambique ranch, lake Mozambique, $\mathrm{N}$ end directly in front of main house. ANSP 140762, 1 (male $24.6 \mathrm{~mm} \mathrm{SL}$ ), Metica river, upstream from entrance to lake Mozambique, halfway to entrance to laguna Arrotas. ANSP 140794, 19 (3 males 20.5-24.5 mm SL, 16 unsexed 18.6-29.8 mm SL), same locality as ANSP 139347. ANSP 140830, 34 (9 males 24.5-28.8 mm SL, 2 females $32.9 \mathrm{~mm} \mathrm{SL}$, 23 unsexed 21.7-31.7 mm SL), confluence of río Guayariba and río Metica. FMNH 84037, 4 (1 unsexed 26.7, 3 males 26.6-28.3 mm SL), río Meta, temporary pool near caño Venturosa, at $1 \mathrm{~km} \mathrm{~N}$ Puerto Lopez. ICNMHN 935, 1 (female $40.4 \mathrm{~mm} \mathrm{SL}$ ), Meta, [Cundinamarca], Quebrada Tascona, río Guacavia, [upper río Meta]. INPA 25174, 30 (15 males 23.2-30.0 mm SL, 15 unsexed 24.1-32.0 mm SL), same data as ANSP 139572. MCP 14942, 5 (2 males 27.9-27.6 mm SL, 3 unsexed 23.2-26.8 $\mathrm{mm} \mathrm{SL}$ ), Mozambique ranch, río Metica, just SW of lake Mozambique. MCP 14946, 5 (females 25.7-30.7 mm SL), lake Mozambique, Mozambique ranch N side, formerly 137577. MCP 14952, 5 (females 27.9-32.4 mm SL), same locality as ANSP 139347, formerly ANSP 134733. MCP 14956, 20 (10 males 19.1-24.2 mm SL, 10 unsexed 14.9-23.3 mm SL), formerly ANSP 139579. MCP 14964, 10 (4 males 29.2-31.6 mm SL, 8 unsexed 28.2-32.1 mm SL), formerly ANSP 131977. MCP 14965, 20 (3 males 23.8-26.4, 17 unsexed 22.3-28.0 mm SL), formerly ANSP 139472. MCP 14966, 20 (7 males 25.1-30.8 mm, 13 unsexed 29.6-34.4 mm SL), formerly ANSP 131976. MCP 14975, 20 (1m male $29.5 \mathrm{~mm} \mathrm{SL}, 1 \mathrm{~m}$ female $29.6 \mathrm{~mm} \mathrm{SL}, 18$ unsexed 16.2-23.2 mm SL), formerly ANSP 139485. MCP $38863,19 \mathrm{~m}$ of 49 (9 males $22.4-29.9 \mathrm{~mm}$ SL, 1 male $30.6 \mathrm{~mm}$ SL c\&s, 3 females $32.0-33.4 \mathrm{~mm} \mathrm{SL}, 1$ female $30.8 \mathrm{~mm}$ SL c\&s, and 5 unsexed 24.2-22.8 mm SL), formerly ANSP 139572. MHNG 2171.39, 2 (unsexed 26.7-28.3 mm SL), Villavicencio, upper río Meta. MHNG 2171.82, 2 (unsexed 20.8-21.4 mm SL), floodplains, caño Carupa of río Guachariria. Golfo de Paria coastal drainage, VENEZUELA, MONAGAS: ANSP 150112, 9 (1 male $29.7 \mathrm{~mm}, 8$ unsexed 26.7-34.1 mm SL), río Pina, $6 \mathrm{~km} \mathrm{~N}$ of Maturín, [Golfo de Paria]. MCP 14970, 8 (unsexed 25.5-32.2 mm SL), formerly ANSP 150112. INHS 31438, 11 (2 males 27.2-34.7 mm SL, 9 unsexed 18.9-38.4 mm $\mathrm{SL})$, río De Oro, río Guarapiche- río San Juan drainage, $4 \mathrm{~km} \mathrm{SW}$ Jusepín. INHS 31461, 14 (unsexed 18.8-33.6 mm SL), río Guanipa (Caribbean Sea Dr.), $20 \mathrm{~km}$ SSE Maturín on hwy. 10. INHS 31485, 9 (unsexed 19.7-25.9 mm SL), río Tigre, $50 \mathrm{~km}$ of Maturín, rt. 10 bridge. USNM 163149, 11 (8 males 27.9-31.9 mm SL, 3 unsexed 31.1-37.3 mm SL), Caicara, Guarapiche river. Río Orinoco basin, VENEZUELA, ANZOATEGUI: ANSP 159909, 7 (unsexed 21.9-27.2 $\mathrm{mm} \mathrm{SL}$ ), río Orinoco at Soledad boat launch just below Puente Angostura. INHS 61950, 14 (4 males 23.8-26.8 mm SL, 10 unsexed 20.9$28.3 \mathrm{~mm} \mathrm{SL}$ ), [río Caris], in hato El Moron, SE of El Tigre. VENEZUELA, BOLIVAR: ANSP 160790, 5x of 40 (unsexed 20.0-31.6 $\mathrm{mm} \mathrm{SL}$ ), river and flooded area $15 \mathrm{~km} \mathrm{~N}$ of Maniapure on Caicara Puerto Ayacucho hwy (río Chaviripa?). ANSP 160819, 20 (1 male $29.2 \mathrm{~mm} \mathrm{SL}, 19$ unsexed 20.9-35.1 mm SL), small stream crossing Caicara - Puerto Ayacucho hwy $18 \mathrm{~km} \mathrm{~N}$ of Maniapure. USNM 233520, 95 (unsexed 16.1-23.4 mm SL), río Orocopiche, ca. $15 \mathrm{~km}$ from mouth in río Orinoco, downstream from route 19 bridge, $08^{\circ} 03^{\prime} \mathrm{N}$ $63^{\circ} 40^{\prime} \mathrm{W}$. VENEZUELA, DELTA AMACURO: USNM 233359, 97 (unsexed 18.3-25.0 mm SL), río Orinoco, small caño on w side just above downstream mouth of caño Remolinos, 74 nautical miles upstream from Sea Buoy. USNM 233652, 37 (unsexed 19.8-31.8 mm $\mathrm{SL}$ ), río Orinoco, backwater caño Araguao, 112 nautical miles upstream from Sea Buoy. USNM 233689, 6 (unsexed 23.7-26.7 mm SL), río Orinoco, lagoon at caño Araguaito, $c a$. km 130. VENEZUELA, MONAGAS: USNM 233745, 31 (1 male $25.5 \mathrm{~mm}$ SL, 30 unsexed 18.6-26.8 mm SL), río Orinoco, Barrancas, laguna El Guatero, 143 nautical miles upstream from Sea Buoy. Río Essequibo basin, Cuyuní drainage, VENEZUELA, BOLIVAR: CAS 70907, 9 (unsexed 19.9-23.6 mm SL), río Carichapo, $30 \mathrm{~km} \mathrm{E} \mathrm{of} \mathrm{Upata,} 200 \mathrm{~km} \mathrm{E}$ of ciudad Bolivar. INHS 31574, 5 (unsexed 20.7-27.0 mm SL), río Oronata, río Yuruari drainage, between Upata \& El Manteco. INHS 31625, 20 (2 males 24.7-25.2 mm SL, 1 female $26.6 \mathrm{~mm} \mathrm{SL}, 17$ 
unsexed 19.9-25.4 mm SL), tributary of río Yuruari, $3 \mathrm{~km} \mathrm{~W}$ Guasipati via La Pastora. INHS 31662, 7 (unsexed 21.2-26.2 mm SL), tributary of río Yuruari, near La Pastora, W of Guasipati. INHS 31754, 16 (3 males 20.8-23.1 mm SL, 13 unsexed 20.7-28.5 mm SL), río Corumo, E Tumeremo on road to Bochinche. INHS 31718, 23 unsexed 17.9$23.7 \mathrm{~mm}$ SL, río Guanare, río Yuruari drainage, El Miamo. INHS 31744, 14 (4 males 21.4-24.5 mm SL, 7 females $22.8-25.5 \mathrm{~mm} \mathrm{SL}, 3$ unsexed 21.2-21.6 mm SL), tributary of río Corumo, E Tumeremo on road to Bochinche. Río Apure basin, VENEZUELA, GUARICO: ANSP 139544, 7 (unsexed 22.7-25.5 mm SL), Camaguán swamp, on W side of highway to San Fernando de Apure, ca. $2 \mathrm{~km} \mathrm{~N}$ of Camaguán. ANSP 141553, 16 (unsexed 16.3-26.6 mm SL), río Orituco, tributary of río Guarico, $15 \mathrm{~km}$ SSE of Calabozo on Cazorla Road. ANSP 149992, 4 (2 males 31.0-32.8 mm SL, 2 unsexed 22.4-25.9 mm SL), [upper río Guarico], lagoon 2-15 km SW El Sombrero. ANSP 163489, 7 (3 males 23.2-24.5 mm SL, 4 unsexed 25.6-25.9 mm SL), río Portuguesa; caño Falcón, laguna La Raya near Camaguán. CAS 70882, 3 (2 males 26.1$25.8 \mathrm{~mm} \mathrm{SL}, 1$ female $28.0 \mathrm{~mm} \mathrm{SL}$ ), spring brook, a tributary to río Guarico, $5 \mathrm{~km}$ south of Calabozo. CAS 70906, 30 of 119 (unsexed 19.0-34.2 mm SL), spring brook, tributary of río Guarico, $6 \mathrm{~km}$ southwest of Calabozo. MCP 14961, 6 (unsexed 18.2-25.3 mm SL), formerly ANSP 139544. MCP 14976, 16 (unsexed 16.8-28.4 mm SL), formerly ANSP 141553. USNM 260590, 10 (unsexed 18.8-28.8 mm SL), río Orituco where crossed by road from Calabozo. VENEZUELA, APURE: ANSP 140752, 12 (unsexed 19.0-28.7 mm SL), río Apure, S bank and backwater areas downstream side of bridge at San Fernando de Apure. INHS 28049, 17 (unsexed 18.6-26.7 mm SL), río Arauca overflow pool, upper río Apure, north edge of Elorza. INHS 89783, 22 (unsexed of 140 13.5-16.9 mm SL), caño Caicara, río Matiyure drainage, $c a$. $15 \mathrm{~km} \mathrm{SSW} \mathrm{Mantecal} \mathrm{on} \mathrm{Bruzual-Elorza} \mathrm{road.} \mathrm{USNM}$ 260598, 28 (16 males 28.3-35.0 mm SL, 11 unsexed 19.4-22.9 mm SL), Centro de Recria M.A.C. - Mantecal, pools along side of road about $2.5 \mathrm{~km}$ south of road from Mantecal. USNM 260601, 21 (3 males 21.1-22.2 mm SL, 18 unsexed 21.2-29.5 mm SL), side channel of río Apure ca. $5 \mathrm{~km}$ west of San Fernando de Apure. USNM 330330, 2 ( 1 male $25.1 \mathrm{~mm} \mathrm{SL}, 1$ female $25.3 \mathrm{~mm} \mathrm{SL}$ ), modulos experimentales de Mantecal. VENEZUELA, PORTUGUESA: CAS 64404, 4 (unsexed 19.3-30.7 mm SL), caño Maraca en el puente $60 \mathrm{~km}$ via GuanareGuanarito road. FMNH 96160, 20 (1 male $31.1 \mathrm{~mm} \mathrm{SL}, 19$ unsexed 25.4-31.2 mm SL), Guanare, río Maria, side pool, $800 \mathrm{~m}$ upstream from bridge, $4 \mathrm{~km}$ E of Guanare. INHS 54553, 20 (unsexed of 48 16.7$22.8 \mathrm{~mm}$ SL), caño Maraca, caño Ignes, río Portuguesa drainage, on road from Guanare to Guanarito at $60 \mathrm{~km}$ marker. INHS 54650, 3 (unsexed 18.0-19.9 mm SL), río Portuguesa, Hwy. 5 bridge. INHS 56134, 1 (unsexed $20.1 \mathrm{~mm} \mathrm{SL}$ ), río Portuguesa, Hwy. 5 bridge. INHS 89824, 6 (unsexed 13.3-16.8 mm SL), caño Mamón, río Portuguesa drainage, El Mamón, 24 km E Guanare. USNM 332091, 10 (1 male $32.0 \mathrm{~mm} \mathrm{SL}, 9$ unsexed 25.6-32.1 mm SL), río Portuguesa, cerca de Nueva Florida. USNM 348669, 1 unsexed (26.3 mm SL), GuanareGuanarito road at road Km 60, $08^{\circ} 49^{\prime} 39^{\prime \prime N} 69^{\circ} 20^{\prime} 42^{\prime \prime}$ W. VENEZUELA, COJEDES: CAS 70884, 45 (1 male $27.6 \mathrm{~mm} \mathrm{SL}, 44$ unsexed 22.4-29.8 mm SL), río Tinaquillo, Orinoco basin. CAS 70901, 14 unsexed 25.9-38.2 $\mathrm{mm} \mathrm{SL}$, same locality as CAS 70884. VENEZUELA, LARA: CAS 70900, 5 (unsexed 19.5-22.4 mm SL), quebrada Seca near Moran, $25 \mathrm{~km}$. S of Barquisimeto. VENEZUELA, TACHIRA: INHS 28152, 27 (4 males 21.0-22.7 mm SL, 23 unsexed 15.1-24.2 $\mathrm{mm}$ SL), tributary of río Doradas, upper río Apure, La Pedrera. VENEZUELA, ARAGUA: INHS 31382, 12 unsexed 26.7-34.7 mm SL, río Guarico, Barbacoas. Río Guaviare basin, COLOMBIA, META: ICNMHN 2956, 9 (1 male 27.3 mm SL, 8 unsexed 21.1-35.9 mm SL), La Macarena, alto raudal, río Santo Domingo. SU 50346, 1 (unsexed $34.5 \mathrm{~mm} \mathrm{SL}$ ), Colombia, río Guaviare basin, vicinity of Los Micos, north end of Cordillera Macarena, $03^{\circ} 20^{\prime} \mathrm{N} 73^{\circ} 56^{\prime} \mathrm{W}$. USNM 181359 , 1 unsexed $20.5 \mathrm{~mm}$ SL, llanos, río Guaviare. Waini River Basin coastal drainage, GUYANA: ROM 67867, 5 (unsexed 28.1-31.5 $\mathrm{mm}$ SL), Barama River, Chinese Landing at base camp, $73^{\circ} 10^{\prime} \mathrm{N}$ 59³3'W. ROM 67868, 11 (5 males 25.2-28.3 mm SL, 6 unsexed 26.2-30.1 mm SL), Barama River, Chinese Landing, $1.5 \mathrm{~km}$ upstream from store, $72^{\circ} 90^{\prime} \mathrm{N} 59^{\circ} 34^{\prime} \mathrm{W}$. ROM 67869, 1 unsexed $29.0 \mathrm{~mm}$ SL, same locality as ROM 67867. ROM 67872, 20 (8 males 25.4-28.2 mm SL, 12 unsexed 19.0-31.3 mm SL), Waini River at Kwabanna next to float plane ramp, $73^{\circ} 40^{\prime} \mathrm{N} 59^{\circ} 09^{\prime} \mathrm{W}$. Rio Amazonas basin, BRAZIL, AMAZONAS: INPA 20980, 1 (male $29.3 \mathrm{~mm} \mathrm{SL}$ ), rio Toototobi, affluent of upper rio Demini, rio Negro drainage, indigenous camp.

Diagnosis. A remarkably long anal-fin base (26.0-33.5\% SL) distinguishes $O$. pulchra from most other Odontostilbe species, e.g. from O. fugitiva (23.5-29.4\% SL) (Fig. 2) the species nearest in distribution (Amazon basin). Only O. nareuda from the rio Madeira basin has a similarly long anal-fin base length (31.3-32.8\% SL), but differs from $O$. pulchra in number of anal-fin rays (24-26 vs 17-24, usually 19-22 in O. pulchra). Furthermore, mature males of $O$. pulchra differ from $O$. fugitiva, $O$. ecuadorensis, $O$. dierythrura, $O$. parecis, $O$. paraguayensis, and $O$. microcephala, and the two new species from the rio Orinoco, $O$. splendida, and $O$. pao, by the presence of hooks on the $1^{\text {st }}$ to $22^{\text {nd }}$ anal-fin branched rays of males, practically on all branched anal-fin rays ( $v s 1^{\text {st }}$ to $9^{\text {th }}$, mostly $6^{\text {th }}-7^{\text {th }}$, anal-fin branched rays of males with hooks); the anal-fin's distal border slightly concave to almost straight in mature males ( $v s$, distal border concave); the longer pectoral fin passing a vertical through pelvic-fin origin ( $v s$ shorter pectoral fin reaching but not trespassing to vertical through pelvic-fin origin, e.g. vs O. fugitiva in Fig. 3), almost absence of elongation of the $2^{\text {nd }}$ unbranched dorsal-fin ray ( $v s$ noticeably elongate $2^{\text {nd }}$ unbranched dorsal-fin ray). Additionally, the longer upper jaw in males, females and unsexed specimens differ $O$. pulchra $(26.8-32.5 \% \mathrm{HL}$ ) from O. fugitiva $(23.4-30.0 \% \mathrm{HL})$ (Fig. 4). Among other characters formerly cited, snout length in males distinghishes $O$. pulchra (18.0-26.0\% HL, mean $21.8 \%$ $\mathrm{HL})$ from the sympatric $O$. splendida $(24.1-26.9 \% \mathrm{HL}$, mean 25.2\% HL), and O. pao (26.7-30.6, mean 28.6\% HL) (Fig. 5).

Description. Morphometric data given in Table 1. Largest male $32.7 \mathrm{~mm}$ SL, largest female $36.9 \mathrm{~mm}$ SL. Body elongate and compressed. Greatest body depth at dorsal-fin origin. Snout short, more blunt in males. Head profile gently convex to straight from snout to posterior tip of supraoccipital bone. Predorsal profile slightly convex between posterior tip of supraoccipital bone and dorsal-fin origin, then straight from dorsal-fin origin to caudal peduncle. Ventral profile convex from mouth to anal-fin origin. Anal-fin base straight. Caudal peduncle slightly longer than deep.

Head relatively small. Posterior margin of opercle sinusoidal with upper portion concave and lower portion convex. Mouth terminal. Maxilla obliquely positioned ending at vertical through anterior border of eye, and practically at horizontal through inferior border of eye. Premaxillary teeth 5, bearing 710 cusps; central cusp longest (Fig. 6). Maxilla with 2-3 (mainly 2) teeth bearing 6-10 cusps, cusp number decreasing to posterior tip of maxilla. Dentary teeth 7-9 bearing 1-7 cusps, gradually decreasing in size; first 5-6 teeth large with 5-7 cusps, 1 medium-sized tooth with 5-6 cusps and posterior teeth very small decreasing from 5 cusps to conical. Smaller cusps of large dentary teeth overlap cusps of adjacent tooth or not. 
Dorsal-fin rays ii,9(117). Dorsal-fin origin slightly behind mid length of body, and slightly posterior to pelvic-fin origin. Second unbranched dorsal-fin ray and $1^{\text {st }}-2^{\text {nd }}$ branched dorsal-fin rays longest. Anal-fin rays iv(5), v(103) or vi(9), 17(1), 18(1), 19(10), 20(32), 21(46), 22(21), 23(4), or 24(2). Anal-fin distal border usually concave, slightly concave to almost straight in mature males. Pectoral-fin rays i(117), 10(43), 11(60), or 12 (14). Distal tip of pectoral fin slightly pointed, $1^{\text {st }}$ unbranched pectoral-fin ray and $1^{\text {st }}-3^{\text {rd }}$ branched pectoral-fin rays longer, reaching posterior to vertical through pelvic-fin origin in males. Pelvic-fin rays i(117), 6(2), 6i(2), 7(112), or 7i(1). Unbranched pelvic-fin ray slightly elongate, reaching to or slight posterior to anal-fin origin in males. Epithelium from external border of unbranched pectoral-fin ray and unbranched pelvic-fin ray thickened in males. Principal caudal-fin rays $16(1), 18(1), 19(112)$, or 20(2). Procurrent caudal fin rays: dorsal 10(12), 11(36), 12(51), 13(16), or 14(1), ventral 8(11), 9(52), $10(43)$, or 11(8). Some dorsal and ventral procurrent caudalfin rays laterally expanded or bifurcated. Caudal-fin ray flaps ventrally on $4^{\text {th }}-7^{\text {th }}$ rays of upper lobe, dorsally on $13^{\text {th }}-16^{\text {th }}$ $\left(\right.$ most $13^{\text {th }}-15^{\text {th }}$ ) rays of lower lobe. Adipose-fin at vertical through last anal-fin ray insertion.

Males with acute well-developed retrorse hooks on medial margin of pelvic-fin rays and posterior margin of anal-fin

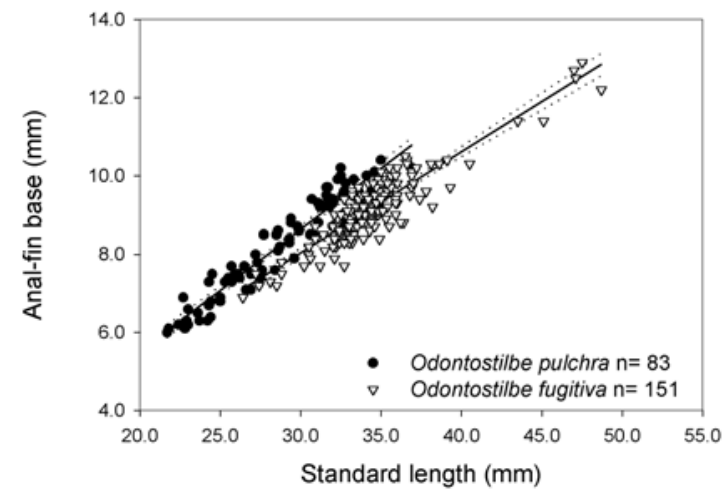

Fig. 2. Anal-fin base length as a function of standard length for males of Odontostilbe pulchra, against $O$. fugitiva.

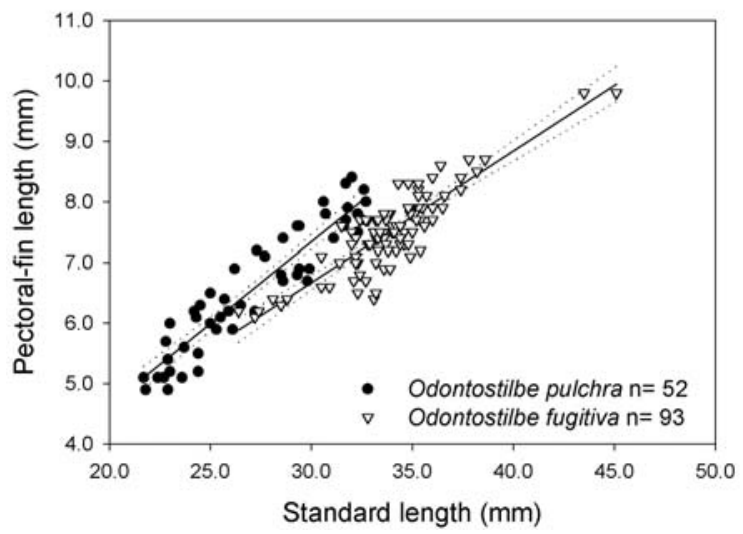

Fig. 3. Pectoral-fin length as a function of standard length for males of Odontostilbe pulchra, against $O$. fugitiva. rays. One to three paired and unpaired hooks per segment of lepidotrichia at distal half-length of last unbranched anal-fin ray and $1^{\text {st }}$ to $22^{\text {th }}$ branched anal-fin rays. One to three unpaired and long hooks per segment of lepidotrichia on $1^{\text {st }}$ unbranched pelvic-fin rays ( 3 specimens) on midlength portion, and on $1^{\text {st }} 7^{\text {th }}$ branched pelvic-fin rays, on midlenght portion through distal tip of fin ray. One or two unpaired hooks per segment of lepidotrichia on lateral or anterior border of branches in a few to several pelvic- and anal-fin rays.

Scales cycloid: lateral line complete 33(6), 34(51), 35(28), $36(5)$, or 37(1); predorsal row 9(3), 10(84), 11(25), or 12(2); scale rows between lateral line and dorsal-fin origin $\mathbf{5}(49)$, or $6(64)$; scale rows between lateral line and anal-fin origin $3(14)$, or 4(102). Scale rows around peduncle 14(102). Triangular modified scale on pelvic-fin base extends posteriorly covering 2 scales. Scales on anal-fin base 6 or 7 .

Cleared and stained specimens (12), x-rays (18): supraneurals 4(18), 5(2); precaudal vertebrae, including Weberian apparatus, 14(1), 15(26), or 16(3); caudal vertebrae 17(9), 18(17), or 19(4); gill rakers (8 c\&s), upper 6(3), or 7(5), lower 11(7), or 12(1) (2-3 on hypobranchial). Alcohol specimens (64): gill rakers, upper 5(4), 6(48), or 7(12), lower 10(4),

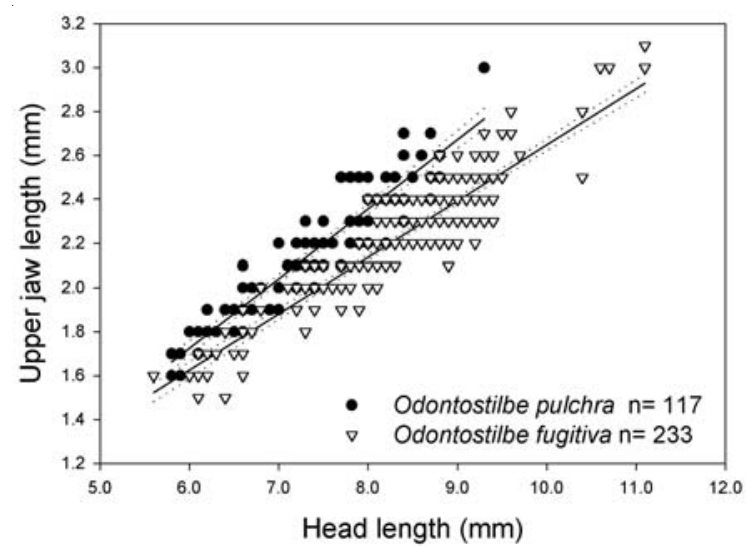

Fig. 4. Upper jaw length as a function of head length for males, females and unsexed specimens of Odontostilbe pulchra, against $O$. fugitiva.

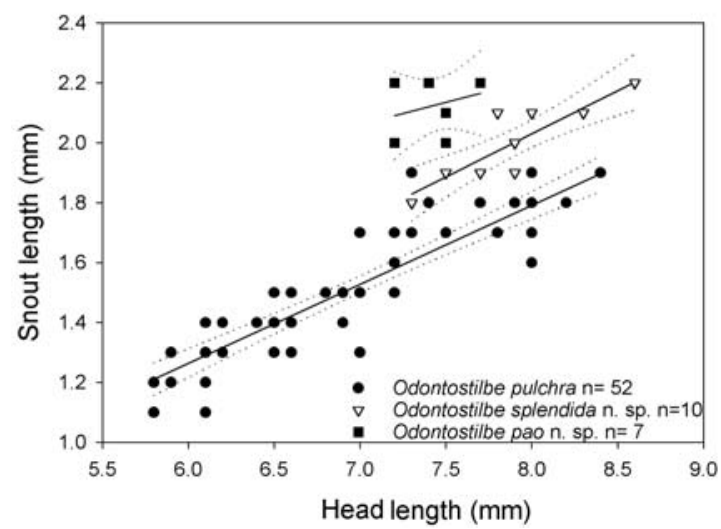

Fig. 5. Snout length as a function of head length for males of Odontostilbe pulchra, against $O$. splendida, and O. pao. 
11(45), or 12(15). Upper gill rakers with 1-4 denticles along anterolateral border, and 1-2 similar denticles on posterolateral border; lower gill rakers with 1-6 denticles on anterolateral border, and none or 1 on posterolateral surface; and posteriormost lower gill raker with none to 2 denticles on posterolateral border, and none to 3 denticles on anterolateral border (Fig. 7). Denticulation mainly on basal portion of gill rakers.

Color in alcohol. General ground body color pale beige, pale orange, or brownish in syntypes. Dorsum with small dark chromatophores from head to caudal peduncle, chromatophores more concentrate on scales border. Scattered dark chromatophores on scales on pseudotympanum area, extending over lateral line. Dark chromatophores along all dorsal-fin rays, ex-

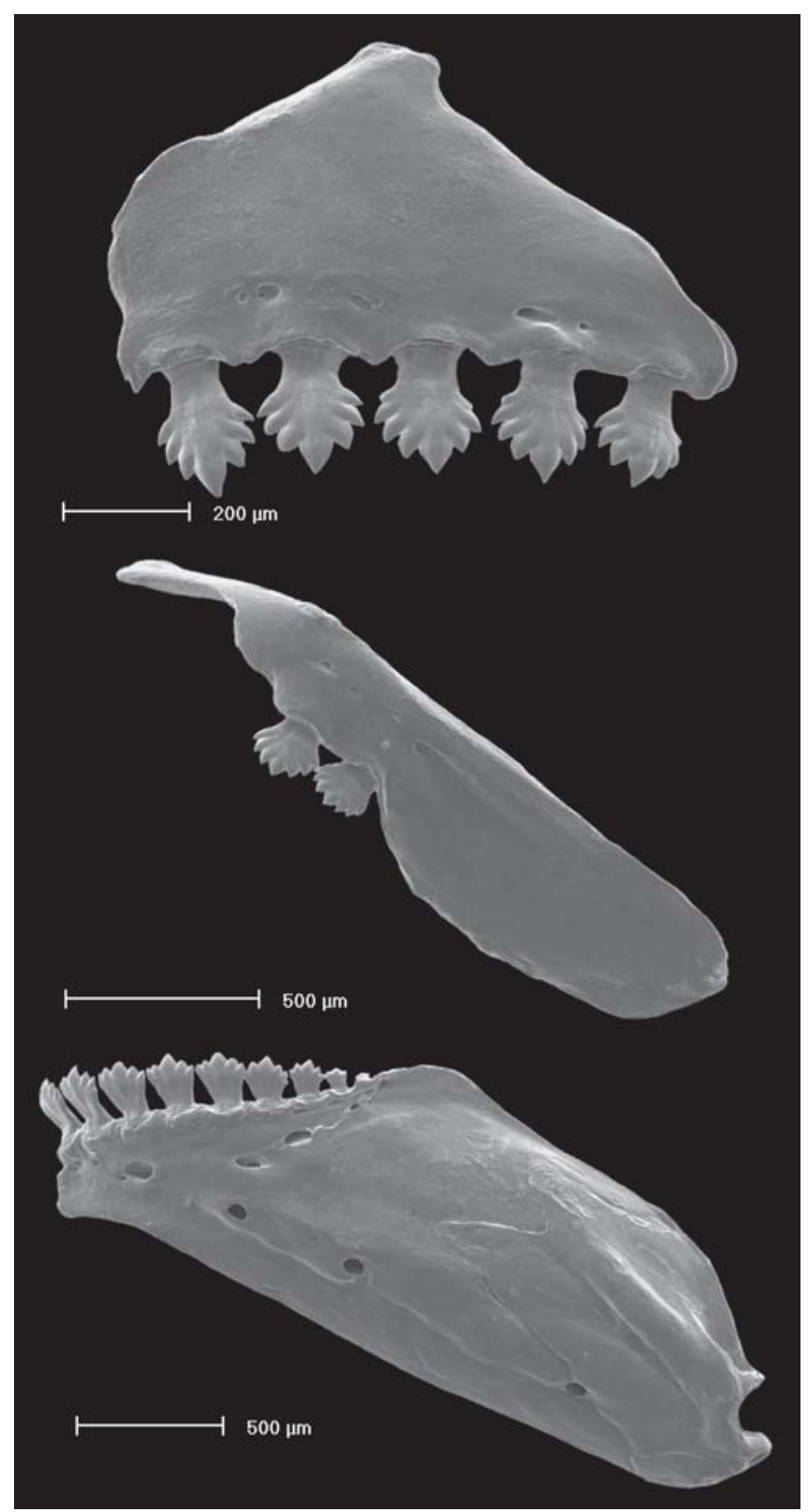

Fig. 6. Dentition of Odontostilbe pulchra, INHS 40101, male $32.5 \mathrm{~mm}$ SL: left premaxilla (top), maxilla (middle), and dentary (bottom), lateral view. Scanning electron micrograph (SEM). cept last branched fin ray only pigmented near fin base; $1^{\text {st }}$ and $2^{\text {nd }}$ unbranched dorsal-fin rays strongly pigmented. All anal-fin rays with chromatophores, more concentrated on distal halflength, last unbranched fin ray and $1^{\text {st }}$ branched fin ray less pigmented. All pectoral-fin rays with dark chromatophores, gradually fading to posterior branched rays, $1^{\text {st }}$ unbranched pectoral-fin ray more pigmented. Pelvic fin clear or with some scattered chromatophores (two specimens). Caudal fin almost entirely covered with diffuse dark chromatophores, except for a light area near caudal-fin spot. Rounded black caudal spot, reaching upper border of caudal peduncle.

Black chromatophores on snout, upper and lower lips, anteriormost portion of maxilla, and anteriormost portion of dentary. Abundant dark chromatophores on fontanel, frontals and parietals, deep-lying chromatophores over brain membrane below frontals and parietals. Body with faint dark and silver midlateral stripe, along middle longitudinal body axis, beginning posterior to pseudotympanum, above lateral line, and reaching caudal spot. Guanine on eye iris, opercle, isthmus, and circumorbital series. Below lateral line, belly faint practically without pigmentation, chromatophores just above anal-fin base forming about 10 chevron shaped markings.

Ground body coloration of syntypes dark brown, faded chromatophores forming caudal-fin spot and the mentioned silvery longitudinal stripe along body.

Color in life. Notes of UMMZ 189000: orange-red in anal, dorsal and caudal fins; center of caudal fin colorless. Regan (1906) described: "olivaceous; sides silvery or a silvery longitudinal stripe from operculum to base of caudal; an indistinct dark humeral spot; a blackish spot at the base of caudal, posteriorly ending in a point and margined with yellow above and below; dorsal and anal pink."

Sexual dimorphism. As mentioned males have hooks on analand pelvic-fin rays. There is no elongation of the second unbranched dorsal-fin ray, but a slight elongation of the unbranched pelvic-fin ray, and the anal-fin distal border is less concave than in females (Fig. 1). The pectoral-fin and the distance from snout to dorsal-fin origin are longer in males than in females (Figs. 8-9). The snout is usually more developed in males (Fig. 10). A gill gland is present on the first gill arch of mature males, including about 8 to 11 anterior branchial filaments (Fig. 7).

Remarks on the type material. Poecilurichthys pulcher was described by the American naturalist Theodore Gill in the year he traveled to the West Indian Islands. He departed in January, 1858 (Dahl, 1916), and resided in Trinidad for several months "through portions of the spring and summer" (Gill, 1858). The description of P. pulcher did not refer to any cata$\log$ number, but Gill (1858: 371) remarked: "specimens of most of the species which are being described have been deposited in the museum of the Smithsonian Institution, and in the private cabinets of Messrs. Stewart and Brevoort." Therefore, not all type specimens would have been deposited at 

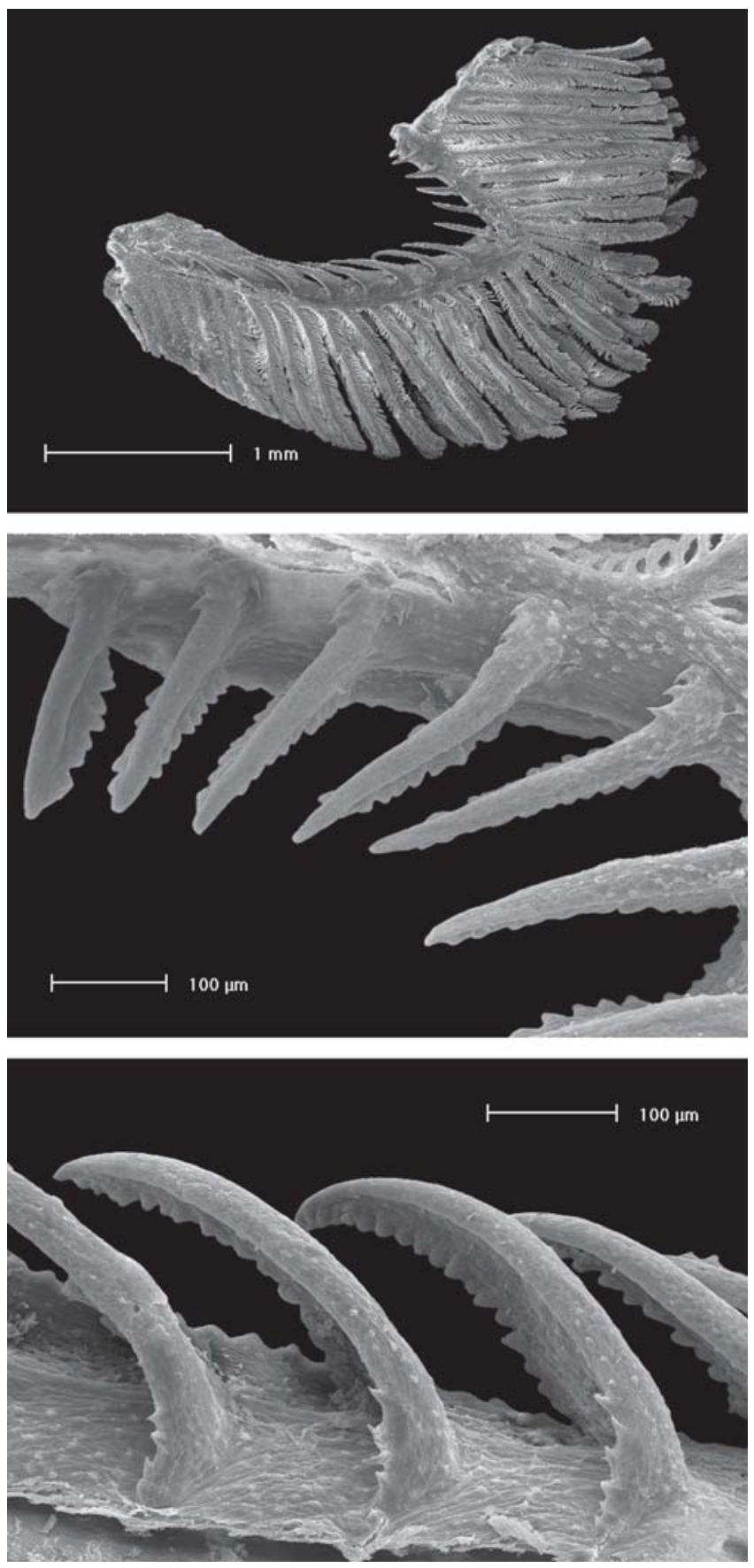

Fig. 7. First gill arch of Odontostilbe pulchra: left side, lateral view, showing gill gland (top) of FMNH 84037, male $26.6 \mathrm{~mm}$ SL, in detail gill rakers on upper branchial branch (middle), and gill rakers on lower branchial branch (bottom) of MCP 38863, male 27.2 mm SL. Scanning electron micrographs (SEM).

Smithsonian. The Smithsonian catalog of type specimens of Characiformes (Vari \& Howe, 1991) did not mention the type material of P. pulcher Gill, 1858, though referred to the syntypes of Poecilurichthys brevoortii Gill, 1858, which are the unique type material found at Smithsonian among other new species of characins described by Gill in that year.

Later in 1875, the Danish zoologist Christian F. Lütken redescribed Chirodon (Odontostilbe) pulcher from Trinidad, moving it from Poecilurichthys Gill to Chirodon Girard. Regarding $C$. (O.) pulcher specimens examined for his study, Lütken explained that they were from Trinidad (1875: 220221): "From the 11 species of this family - Characinidae - from Trinidad that Prof. Gill carried home, the Museum has obtained about seven through the Judicial Counselor Mr. Riise, and further one that Mr. Gill overlooked: when all of these have been unknown by Günther; and because of insufficient descriptions he was unable to arrange Tetragonopterins in their systematic place, here these species are the object for some remarks or partly for complete descriptions" [our translation]. Coincidentally, Prof. Gill is the American naturalist that described the species in 1858, and Mr. Riise the man honored in the description of Corynopoma riisei Gill, 1858 (Gill, 1858: 427): "Mr. A. H. Riise of the Danish Island of St. Thomas, the gentleman to whom this species has been dedicated, is well known as one of the most active zoologists of the West Indies, and has greatly contributed to our knowledge..., by his contributions to Dr. Louis Pfeiffer, and to Dr. A. Lütken" [our translation]. Further detailing Mr. Riise's contribution to the Zoological Museum of Copenhagen (ZMUC), Lütken (1875: 223) wrote under diagnosis of Corynopoma Gill: "In this small collection of fishes from Trinidad, which Prof. Gill gave to Mr. Riise at that time and whom again gave it to the Museum,..." [our translation], in a foot note, Lütken

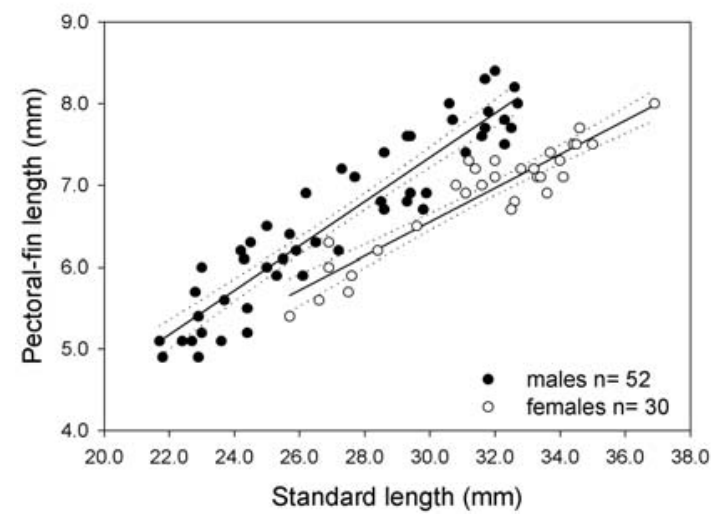

Fig. 8. Pectoral-fin length as a function of standard length for males against females of Odontostilbe pulchra.

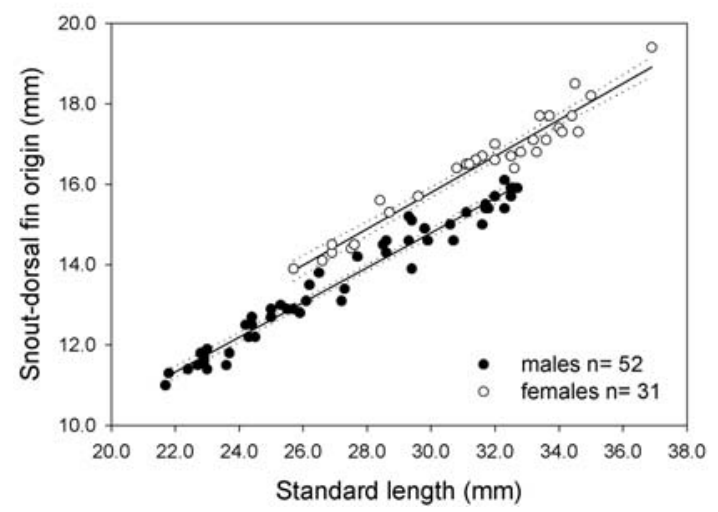

Fig. 9. Snout-dorsal fin origin as a function of standard length for males against females of Odontostilbe pulchra. 


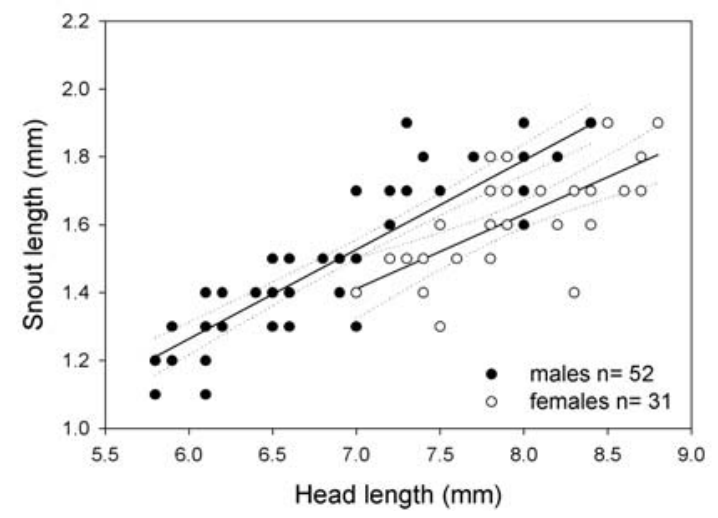

Fig. 10. Snout length as a function of head length for males against females of Odontostilbe pulchra.

(1875: 222): "The Justice Counselor Mr. Riise donated to the Museum eigth species of Characins and four Siluroids from Trinidad" [our translation].

Considering what is mentioned above, Lütken's (1875) species redescriptions of the characins from Trinidad, which had been previously described by Gill (1858), could have been based on type material or related material caught at the time Gill was in Trinidad. As Lütken worked at ZMUC from 1852 to 1899 (Alves \& Pompeu, 2001), the type material of Poecilurichthys pulcher Gill could have been donated to him through Riise and Gill. However, the type material of P. pulcher Gill is not listed in the "Catalog of fish types of Zoological Museum of Copenhagen" (Nielsen, 1974), and not found in ZMUC (personal communication of Dr. Jörgen G. Nielsen, ZMUC curator).

During the course of this study, two specimens of $O$. pulchra obtained on loan from the Muséum d'Histoire Naturelle de Paris (MNHN), have been proven to be the Lütken (1875) specimens. The two fishes were donated to MNHN from ZMUC with the following information: "Museum of Copenhague (Reinhardt and Lütken) 1876. Provenance: Trinidad" (Patrice Pruvost, MNHN, personal communication). In Lütken's (1875) redescription, $C$. (O.) pulcher was redescribed probably on the basis of two specimens as indicated by lateral line, dorsal-fin and anal-fin ray counts in $\mathrm{p}$. 238: “...33-34 scales along the entire lateral line, ... D: 10.11 (2.8-9); ... A: 23-25 (3-4 + 20-21)" [our translation]. These two specimens, MNHN 0000-9593, examined herein match these counts of C. pulchra by Lütken (1875) and other characters: a- each dentary with 7 teeth; b- 5 transversal scale series above lateral line; c- 33-34 lateral line scales; d- dorsal fin 10.11, including 1 or 2 unbranched dorsal-fin rays plus 9 branched dorsal-fin rays; e- pectoral fin 12 , not including the $1^{\text {st }}$ unbranched fin ray, f- ventral fin 8 , including the $1^{\text {st }}$ unbranched pelvic-fin ray; and g- anal fin 23-25 (3-4 +20-21), 4 unbranched fin rays plus 20 unbranched fin rays. The external morphology and color descriptions of Lütken's specimens fit the two MNHN specimens, for example: "Pectoral fins reach to pelvic fins,...", or "The white lateral band and the dark shoulder and caudal spots are generally enough distinct; however the spots of the shoulder may be lacking" [our translations]. The white lateral band is actually silver, and remains in the two specimens (Fig. 1). The "shoulder spot" is the pseudotympanum. Therefore, MNHN 0000-9593 specimens match those examined by Lütken (1875).

After Lütken's 1875 redescription of $C$. (O.) pulcher, there were no more citations found refering to further examinations of Gill's type material. Britski (2001) stated that there is a lower number of type specimens in the Museum of Zoology of Copenhagen than the number of species described in another Lütken's study about fishes of the Rio das Velhas, and suggested that part of the type material was lost or donated to different museums, as is the case of the syntypes of Leporinus reinhardti Lütken, 1875 and L. taeniatus Lütken, 1875 currently deposited at MNHN.

Based on the evidences presented above, mainly the donation of the characins from Trinidad by Gill to Riise, and then to Lütken, the two specimens of MNHN 0000-9593 are herein recognized as the syntypes of Odontostilbe pulchra. Gill's (1858) description of that species seems to be based on one specimen, and matches dorsal-fin, anal-fin and pelvic-fin ray counts of one specimen of MNHN 0000-9593, p. 419: "D. 10. A. 22 ...V.8.". Probably unbranched and branched fin rays were jointly counted by Gill, and the anal-fin ray count is 20 branched anal-fin rays. Despite of that indication for the existence of an holotype, we prefer to consider the two as syntypes because they were collected together, and remained in the same jar after Lütken's examination.

The following incorrect information was found on the label of the two syntypes MNHN 0000-9593: a- Area: Uruguay, Locality: Trinidad; b- Collectors: Reinhardt, Lütken, c- Date: 1976. These data were corrected to: a- Area: none information, Locality: western portion of Trinidad; b- Collectors: unknown; c- Date of determination: 1876 by Johannes T. Reinhardt and Christian F. Lütken; d- Date of collection: 1858. This date of collection is based on the biography of Gill by Dahl (1916), in which he confirmed that the visit to Trinidad occurred in 1858 between January and August (p315): "Gill sailed in January, 1858...He went to Washington in August 1858...". Notes supporting corrections: (1) the city Trinidad in Uruguay is localized on the margin of río La Plata basin, where there are no cheirodontines with lateral line complete with 34-35 scales, number of ventral procurrent caudal-fin rays $8-11$, plus dentary teeth with seven cusps (differing of Heterocheirodon spp., Cheirodon spp., and Holoshesthes pequira, the cheirodontines present in La Plata basin); (2) Lütken examined the syntypes, probably also Reinhardt as he worked with Lütken, but there is no evidence that they had been collecting in Trinidad, Uruguay in 1876; (3) additional information from MNHN files (through Patrice Pruvost personal communication) confirming origin of the material from ZMUC, Denmark.

The syntypes are somewhat damaged with broken fins (Fig. 1, top). Specimen $28.7 \mathrm{~m}$ SL lacks most premaxillary and maxillary teeth, but the other female $30.8 \mathrm{~mm}$ SL has entire dentition preserved on premaxilla and maxila, and some 
Table 1. Morphometrics of Odontostilbe pulchra (syntypes MNHN 0000-9593) (Trinidad drainages, INHS 40081, INHS 40101, ROM 41069, ROM 44764, USNM 290410; río Orinoco basin, ANSP 139450, ANSP 139579, ANSP 139472, MCP 14975, MCP 38863; rio Amazonas basin, INPA 20980).

\begin{tabular}{|c|c|c|c|c|c|c|c|c|c|c|c|c|c|c|}
\hline \multirow[b]{3}{*}{ Standard length $(\mathrm{mm})$} & \multirow{2}{*}{\multicolumn{2}{|c|}{$\begin{array}{l}\text { Females } \\
\text { Syntypes } \\
\end{array}$}} & \multicolumn{4}{|c|}{ Males } & \multicolumn{4}{|c|}{ Females } & \multicolumn{4}{|c|}{ Unsexed } \\
\hline & & & \multirow{2}{*}{$\begin{array}{c}\mathrm{n} \\
52\end{array}$} & \multirow{2}{*}{$\begin{array}{l}\text { Low } \\
21.7\end{array}$} & \multirow{2}{*}{$\begin{array}{c}\text { High } \\
32.7\end{array}$} & \multirow{2}{*}{$\begin{array}{c}\text { Mean } \\
27.3\end{array}$} & \multirow{2}{*}{$\begin{array}{l}\mathrm{n} \\
29\end{array}$} & \multirow{2}{*}{$\begin{array}{l}\text { Low } \\
25.7\end{array}$} & \multirow{2}{*}{$\begin{array}{l}\text { High } \\
36.9\end{array}$} & \multirow{2}{*}{$\begin{array}{c}\text { Mean } \\
31.6\end{array}$} & \multirow{2}{*}{$\begin{array}{c}\mathrm{n} \\
32\end{array}$} & \multirow{2}{*}{$\begin{array}{l}\text { Low } \\
23.1\end{array}$} & \multirow{2}{*}{$\frac{\text { High }}{37.2}$} & \multirow{2}{*}{$\frac{\text { Mean }}{28.5}$} \\
\hline & 28.7 & 31.2 & & & & & & & & & & & & \\
\hline \multicolumn{15}{|c|}{ Percents of standard length } \\
\hline Head length & 26.1 & 25.0 & 52 & 24.2 & 28.9 & 25.9 & 29 & 23.8 & 27.8 & 25.2 & 32 & 22.9 & 26.8 & 25.3 \\
\hline Snout-anal fin origin & 62.7 & 64.1 & 52 & 58.6 & 64.0 & 61.9 & 29 & 61.7 & 67.8 & 65.0 & 32 & 57.9 & 67.4 & 63.8 \\
\hline Snout-dorsal fin origin & 53.3 & 52.9 & 52 & 47.3 & 52.1 & 50.0 & 29 & 50.0 & 54.9 & 52.3 & 32 & 46.9 & 54.5 & 51.4 \\
\hline Snout-pelvic fin origin & 44.6 & 43.6 & 52 & 42.3 & 47.9 & 44.8 & 29 & 44.6 & 49.6 & 47.1 & 32 & 41.8 & 50.2 & 46.0 \\
\hline Dorsal-fin base & 13.9 & 15.4 & 52 & 12.4 & 16.5 & 14.6 & 29 & 13.2 & 15.6 & 14.2 & 32 & 13.0 & 15.9 & 14.5 \\
\hline Anal-fin base & 28.6 & 29.5 & 52 & 26.0 & 31.4 & 28.8 & 29 & 26.3 & 30.7 & 28.1 & 32 & 26.0 & 33.5 & 28.4 \\
\hline Caudal peduncle length & 12.2 & 14.4 & 52 & 12.5 & 16.0 & 13.8 & 29 & 11.4 & 14.4 & 13.0 & 32 & 10.0 & 14.3 & 12.8 \\
\hline Caudal peduncle depth & 11.8 & 13.5 & 52 & 10.2 & 12.9 & 11.6 & 29 & 10.5 & 12.5 & 11.6 & 32 & 9.8 & 12.4 & 11.5 \\
\hline Depth at dorsal-fin origin & 37.3 & 41.3 & 52 & 28.0 & 35.9 & 32.7 & 29 & 30.7 & 41.8 & 37.4 & 32 & 29.6 & 41.3 & 34.7 \\
\hline Dorsal-fin length & & 33.7 & 47 & 28.6 & 37.5 & 32.1 & 29 & 28.6 & 33.1 & 30.9 & 29 & 27.4 & 33.4 & 31.6 \\
\hline Pelvic-fin length & 16.7 & 18.3 & 51 & 16.8 & 26.1 & 20.4 & 29 & 16.0 & 19.3 & 17.8 & 32 & 16.1 & 19.9 & 18.0 \\
\hline Pectoral-fin length & & 23.4 & 52 & 21.3 & 26.4 & 24.2 & 29 & 20.5 & 23.4 & 21.7 & 32 & 18.8 & 23.9 & 21.9 \\
\hline Snout-pectoral-fin origin & 25.8 & 23.7 & 52 & 23.5 & 28.7 & 25.8 & 29 & 23.0 & 27.8 & 25.1 & 32 & 23.3 & 27.0 & 25.4 \\
\hline \multicolumn{15}{|c|}{ Percents of head length } \\
\hline Snout length & 17.3 & 19.2 & 52 & 18.0 & 26.0 & 21.8 & 28 & 18.9 & 23.1 & 20.6 & 32 & 18.2 & 23.1 & 20.8 \\
\hline Upper jaw length & 28.0 & 28.2 & 52 & 27.1 & 31.8 & 29.1 & 29 & 27.0 & 32.1 & 29.2 & 32 & 26.8 & 32.5 & 29.6 \\
\hline Horizontal eye diameter & 38.7 & 41.0 & 52 & 34.8 & 41.9 & 38.2 & 29 & 34.5 & 41.0 & 37.6 & 32 & 36.6 & 40.9 & 39.1 \\
\hline Least interorbital width & 29.3 & 33.3 & 52 & 27.9 & 35.0 & 31.9 & 29 & 28.4 & 34.2 & 31.4 & 32 & 28.4 & 34.2 & 31.3 \\
\hline
\end{tabular}

dentary teeth. This female $30.8 \mathrm{~mm}$ SL has the body bent, making measurements difficult. Scales are relatively well-preserved in both specimens.

Distribution. Odontostilbe pulchra occurs on the Island of Trinidad, being registered to the western drainages of the Caroni, Bejucal and O'Meara river drainages, and to the eastern Quare river, Cunapo basin (Fig. 11). An uncertain drainage that is probably on the southeast of Trinidad is referred in the geographical coordinates of CAS 70933, not plotted in the map. It is widespread in río Orinoco basin, smaller coastal drainages of Venezuela, Lake Valencia system, and the río Essequibo basin (Fig. 11).

Information on the distribution of Odontostilbe pulchra based on previous studies is doubtful, since it appears that several undescribed cheirodontine species of the genera Odontostilbe, Serrapinnus and even Holoshesthes, from northern South America have been identified as O. pulchra. The species was described by Price (1955) as "found in Caroni, Caparo and northern Oropouche drainages only and is known to occur in Venezuela as well". Taphorn (1992) provides a map with distribution of "Cheirodon pulcher" for the río Apure basin, but the records are most probably of an undescribed species of Serrapinnus as he mentioned the lateral line being incomplete in the diagnosis of " $C$. pulcher" (complete in $O$. pulchra). "C. pulcher" (Gill, 1858) is cited in the list of fishes from Venezuela (Taphorn et. al., 1997). Lasso et al. (2003) cited C. pulcher to the Orinoco, Cuyuní, Gulf of Paria, Caribbean, and Lake Valencia; all drainages confirmed by examined material in the present study. Lasso et al. (2004) recorded C. pulcher in the río Orinoco basin for the following drainages: upper Orinoco, Ventuari, Atabapo, Meta, Cinaruco, Suarape, Capanaparo, Arauca, Apure, Cuchiviero, Zuata, Caura, Pao,

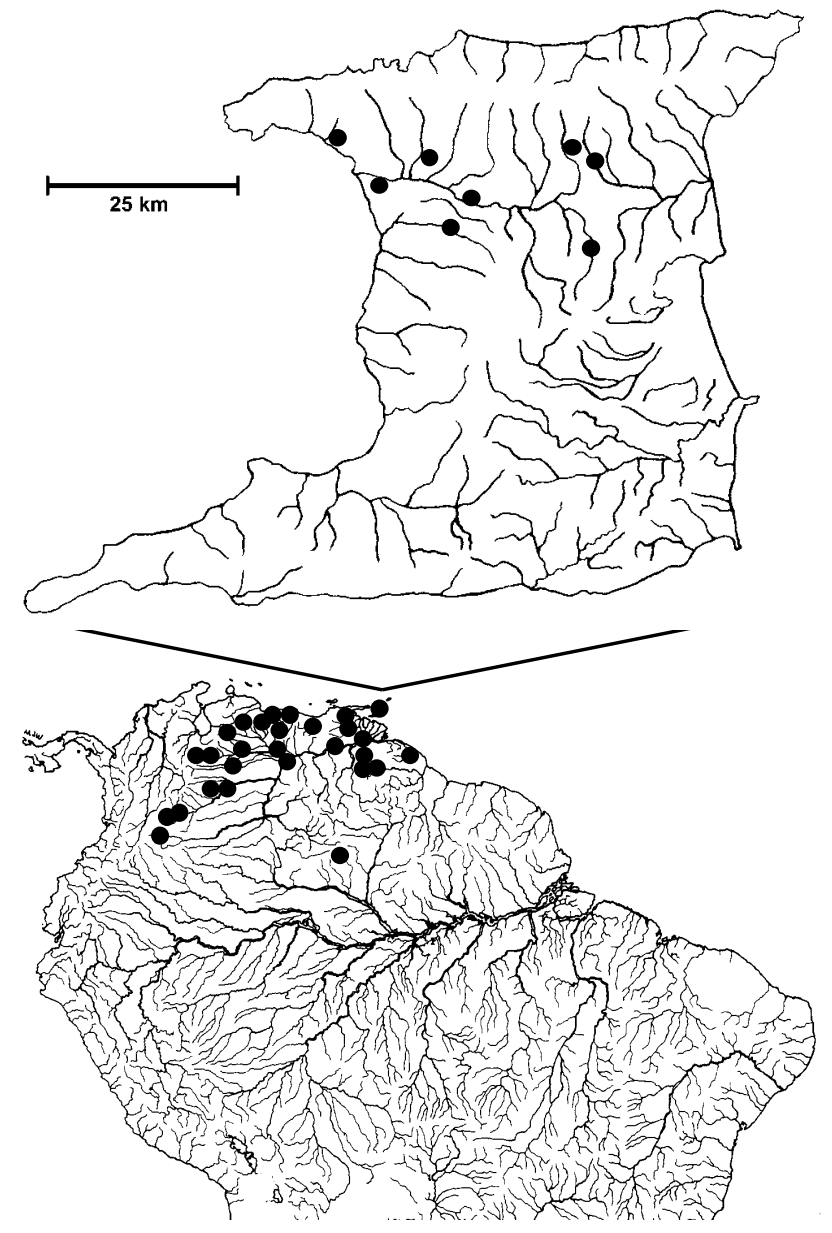

Fig. 11. Distribution of Odontostilbe pulchra. Circles (material examined, symbols can represent more than one lot, and more than one locality). In detail Trinidad map, modified from American Geographical Society of New York (1957). 
Caris, Caroní, Morichal Largo, Delta, and the own Orinoco (most drainages not listed in the material examined herein).

Odontostilbe pulchra is not restricted to the río Orinoco basin and the Island of Trinidad. There is a spot occurrence in the upper rio Demini, rio Negro, Amazonas basin, though represented by an unique mature male (Fig. 11). This is a locality near southern headwaters of the río Orinoco basin, indicating that the species is present in the Orinoco-Amazon basin boundaries. Lasso et al. (1990) discussed the biogeographic history and faunistic similarity between upper río Caroni and the neighbouring rio Branco, rio Negro, mentioning possible connection between these water systems, which could be previous to the uplifting of Sierra de Pacaraima, or through divergent Gran Sabana paleoflowings. The rio Demini, where $O$. pulchra is recorded, runs parallel to rio Branco, thus the occurrence of the typical species of Orinoco as $O$. pulchra might be an evidence of the common biogeographical history for the Orinoco-Amazon basin in this region. The proximate historical relationship between Orinoco and northern Amazon ichthyofauna is hypothesized to date before the Orinoco-Amazonas divide in the Late Miocene by the Vaupes Arch to Guyana Shield on the west to the Serrania de La Macarena (Lundberg et al., 1998). However, there is the alternate hypothesis that the Rupununi inundated savannah is a modern dispersal route to the fishfaunas from upper rio $\mathrm{Ne}$ gro and the rio Essequibo (Hubert \& Renno, 2006).

Ecological notes. As stated above, information of $O$. pulchra based on previous studies is doubtful, since it appears that several undescribed cheirodontine species have been identified as $O$. pulchra. In Trinidad, it is described as "found in drains and ravines in the high woods, Cumuto" (Regan, 1906). In Venezuela, Winemiller (1989) referred to "O. pulcher" as the numerically dominant species in the estero during wet season caño Maraca, a swamp-creek in the floodplain of the western Venezuelan llanos, Apure-Orinoco drainage. " $O$. pulcher" was found in diets of Charax gibbosus, Hoplias malabaricus, Pygocentrus notatus, Caquetaia kraussii, and Gymnotus carapo, being the main food item for $C$. gibbosus between 50-60 mm (Winemiller, 1989). Fish census at the same caño Maraca, totalled 3182 specimens of "O. pulcher", the most numerous fish in the sampled fishfauna (Winemiller \& Pianka, 1990). Taphorn (1992) refers to the species Cheirodon pulcher as "ubiquitous in the piedmont and llanos", "abundant" in Apure River Basin, "slow moving streams and especially in lowland lentic systems". In a table, Taphorn (1992: 500) classified C. pulcher as $r 1$ strategist, omnivorous, occurring in white, clear and blackwaters, abundant, present in both mountains and llanos. R1 strategists are "those species with low juvenile and adult survivorship, low fecundity per reproductive bout, but many bouts per season, a short generation time, and population densities that fluctuate greatly between the wet and dry seasons" (Taphorn, 1992). However, the "C. pulcher" studied by Taphorn (1992), as commented before probably is an undescribed species of Serrapinnus, as he mention the incomplete lateral line in " $C$. pulcher" diagnosis (complete in O. pulchra). Despite of the difficulties in the identification of the species, probably the species has been analysed in many ecological studies as that of Lasso (1992) for the lower Suapure ichthyofauna, listing $O$. pulcher as an important fish in ornamental trade of the Los Pijiguaos region in Venezuela, Flecker (1992) using C. pulcher, a dominant "tetra" in río Las Marias in experiments about trophic guilds, or Jepsen (1997) listing "Chierodon sp. 1 and sp. 2" among the most common fish species taken from sand bank habitats in the Cinaruco River. Recently, Hoeinghaus et al. (2004) reinforces the high abundance of " $C$. pulcher" in the llanos foodplain of the río Portuguesa, remarking it is the most frequently collected species jointly with Roeboides dayi.

\section{Odontostilbe splendida, new species}

Fig. 12

Holotype.ANSP 181040, 1 male (32.7 mm SL), Colombia, Meta, río Negrito at bridge at La Balsa, Meta drainage, J. E. Böhlke et al., 27 March 1975.

Paratypes. ANSP 181041, 30m, (8x of 30), (8 males 29.4-36.4 $\mathrm{mm}$ SL, 1 male $34.7 \mathrm{~mm}$ SL c\&s, 20 females 31.3-41.6 mm SL, 1 female $32.1 \mathrm{~mm}$ SL c\&s), same data as holotype. MCP 38862 , 27 (13 males 28.9-33.6 mm SL, 1 male $29.5 \mathrm{~mm}$ SL c\&s, 13 unsexed 28.5-34.4 mm SL), same data as holotype, formerly ANSP 139572. MCNG 54519, 13 (7 males 29.2-33.2 mm SL, 6 unsexed 30.1-34.4 mm SL), same data as holotype. MBUCV 32890, 13 (7 males 29.3-32.9 mm SL, 6 unsexed 25.8-32.3 mm SL), same data as holotype. ICNMHN 14168, 13 (7 males 29.0$33.0 \mathrm{~mm}$ SL, 6 unsexed 31.0-32.8 $\mathrm{mm} \mathrm{SL}$ ), same data as holotype. INPA 25173, 13 (7 males 29.5-32.2 mm SL, 6 unsexed 29.7-34.2), same data as holotype.

Non types. Río Meta basin, COLOMBIA, META: MHNG 2512.93, 3 (unsexed 22.9-27.0 mm SL), río Humadea, near El Merey basin of río Meta. ANSP 139484, 7 (2 males 32.8-33.9 mm SL, 5 unsexed 29.7-33.6 mm SL), confluence of río Guayariba and río Metica. Río Apure basin, VENEZUELA, GUARICO: ANSP 181137, 50 (1 male $31.1 \mathrm{~mm} \mathrm{SL}, 49$ unsexed 19.2-37.5 mm SL), tributary of río Guarico, $3 \mathrm{~km} \mathrm{~S}$ of Calabozo on federal highway no. 2, formerly ANSP 139696. MCP 14971, 11 unsexed 17.1-31.7 mm SL, río Apure, San Fernando de Apure, formerly ANSP 150111. VENEZUELA, PORTUGUESA: USNM 349419, 7 unsexed 29.9$33.0 \mathrm{~mm}$ SL, río Las Marias, quebrada Seca (town) approximately 45 min. upstream by car from hwy. 5, $22 \mathrm{Km}$ NNW Guanare. Río Orinoco basin, VENEZUELA, BOLIVAR: ANSP 181136, 30 (1 male $32.8 \mathrm{~mm}$ SL, 29 unsexed 26.2-33.5 mm SL), caño Caiman, at crossing of Caicara - Puerto Ayacucho hwy, $19.2 \mathrm{~km} \mathrm{~W}$ of Ciudad Bolivar-Caicara highway, formerly ANSP 159904.

Diagnosis. The anterior position of the adipose fin, at vertical through last $2^{\text {nd }}$ or $3^{\text {rd }}$ anal-fin ray insertions in O. splendida (Fig. 12 ) is noticeably distinct from all other Odontostilbe species, including the sympatric $O$. pulchra (Fig. 1) and O.pao (Fig. 23), in which the adipose fin is positioned at vertical through last anal-fin ray insertion. Odontostilbe splendida further differs from O. pulchra by a group of morphometric characters in males: 
snout pointed and longer in $O$. splendida $(24.1-26.9 \% \mathrm{HL}) v s$ short and blunt in O. pulchra (18.0-26.0\% HL) (Fig. 5), shorter pectoral-fin length (20.9-23.5\% SL in O. splendida vs $21.3-26.4 \%$ SL in O. pulchra) (Fig. 13), smaller anal-fin base (24.9-26.8\% SL vs 26.0-31.4\% SL) (Fig. 14), shorter caudal peduncle length (11.5$13.0 \%$ SL vs 12.5-16.0\% SL) (Fig. 15), longer snout-pelvic fin origin distance (45.1-48.7\% SL vs 42.3-47.9\% SL) (Fig. 16), and longer snout-anal fin origin distance $(63.7-68.6 \% \mathrm{SL} v s$ 58.6-64.0\% SL) (Fig. 17). Additionally, mature males of $O$. splendida are remarkably distinguished by the presence of hooks on $1^{\text {st }}$ to $6^{\text {th }}-7^{\text {th }}$ anal-fin rays, $v s$ hooks on $1^{\text {st }}$ to $22^{\text {nd }}$ anal-fin branched rays in $O$. pulchra. Mature males of $O$. splendida usually have the $2^{\text {nd }}$ unbranched dorsal-fin ray elongate, not present in O. pulchra. Females and immature specimens, and not well-developed males of $O$. splendida and $O$. pulchra, have overlapping ranges in many of the ratios cited above, and can be differentiated by the following characters: (1) presence of 3-4 (mostly 3) maxillary teeth in O. splendida, vs 2-3 (mostly 2) in O. pulchra; 36 lateral line scales (one specimen 35 ) in $O$. splendida vs 33-37, mostly 34-35 lateral line scales in $O$. pulchra. The number of gill rakers counts on lower branch differ $O$. splendida (averaging 11) from $O$. fugitiva (usually 12) (Fig. 18).
Description. Morphometric data are given in Table 2. Largest male $36.4 \mathrm{~mm}$ in.SL, largest female $41.6 \mathrm{~mm}$ in SL. Body elongate and compressed. Body of males slightly more compressed and elongate than females. Greatest body depth at dorsal-fin origin. Snout short, somewhat pointed in males. Head profile pointed, gently convex to straight from snout to posterior tip of supraoccipital bone. Predorsal profile slightly convex to straight between posterior tip of supraoccipital bone and dorsal-fin origin, straight on dorsal-fin base, and then slightly convex to straight from end of dorsal-fin base to caudal peduncle. Ventral profile convex from mouth tip to anal-fin origin. Analfin base straight. Caudal peduncle slightly longer than deep.

Head relatively small. Posterior margin of opercle sinusoidal with upper portion concave and lower portion convex. Mouth terminal. Maxilla obliquely positioned ending at vertical through anterior border of eye, and at horizontal on inferior border of eye. Premaxillary teeth 5-6, bearing 8-11 cusps; central cusp longest (Fig. 19). Maxilla with 3-4 (mainly 3) teeth bearing 5-9 cusps, decreasing cusp number toward posterior tip of maxilla. Dentary teeth 9-10, gradually decreasing in size, anterior 5-6 teeth large bearing 7-8 cusps, 1 medium-sized tooth with 5-6 cusps, and posterior teeth small, conic or with

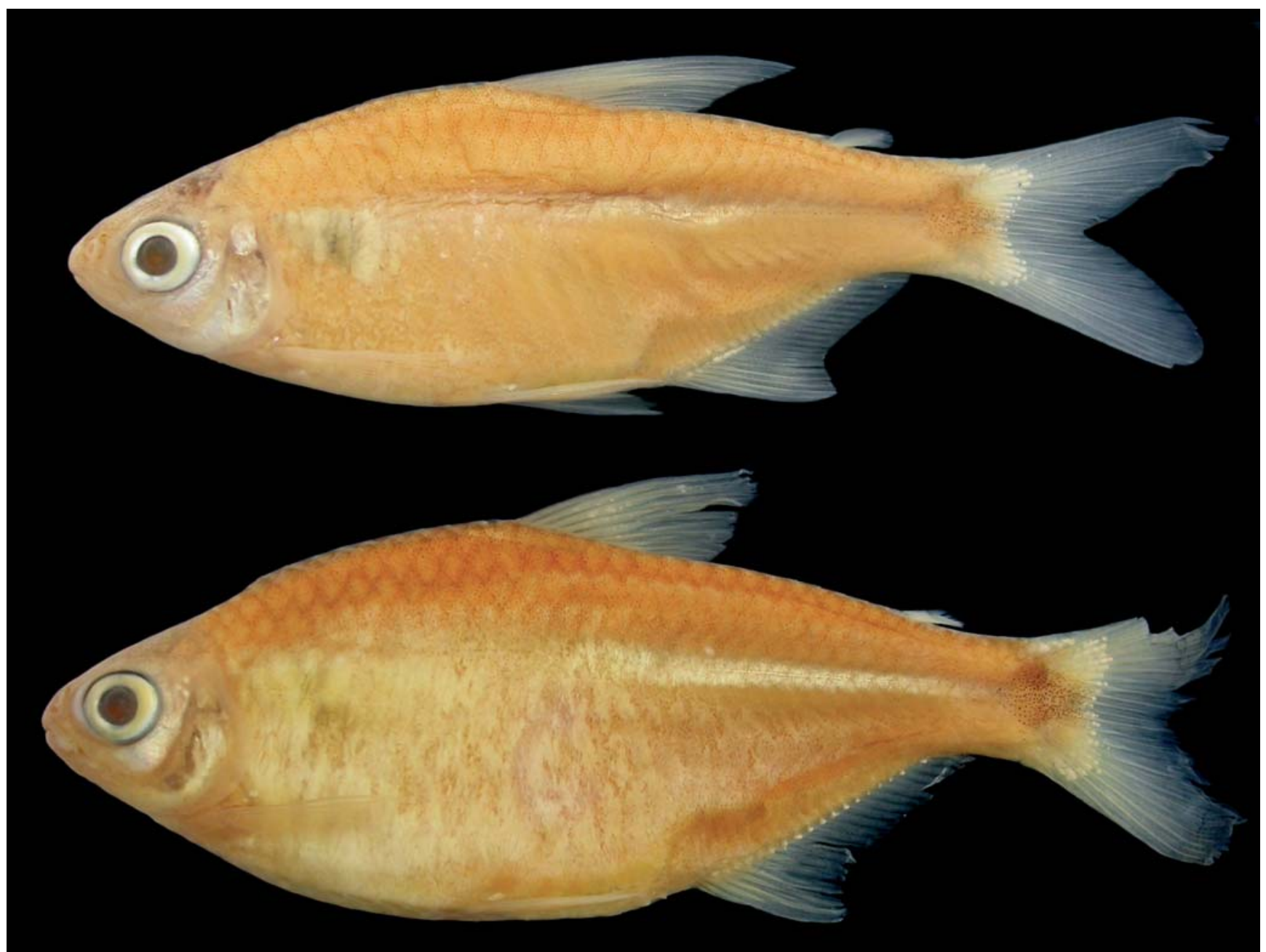

Fig. 12. Holotype of Odontostilbe splendida, ANSP 181040, male $32.7 \mathrm{~mm}$ SL (top), and paratype ANSP 181041, female $32.1 \mathrm{~mm}$ SL (bottom). 
2-5 cusps. Smaller cusps of dentary teeth overlap cusps of adjacent tooth.

Dorsal-fin rays ii,9(31). Dorsal-fin origin slightly posterior to mid body length, and slightly posterior to pelvic-fin origin. Second unbranched dorsal-fin ray slightly elongate in some males (not in holotype), extending beyond dorsal-fin distal profile. Anal-fin rays iv(6), or v(25), 19(9), 20(16), 21(5), or 22(1). Anal-fin distal border concave, anterior 6-7 branched

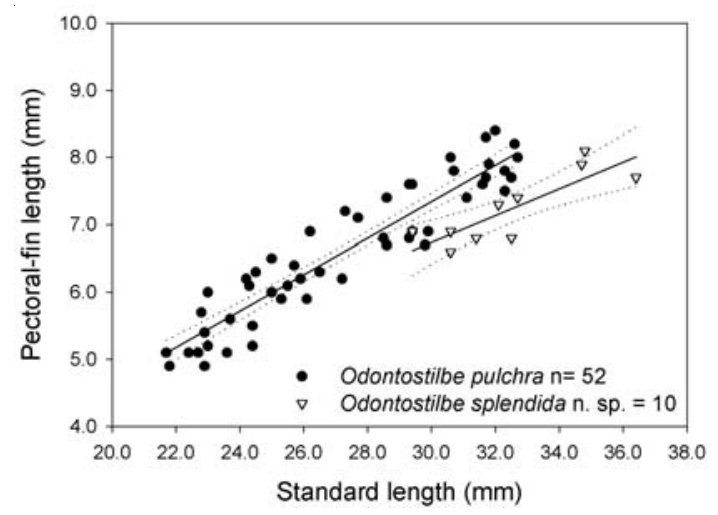

Fig. 13. Pectoral-fin length as a function of standard length for males of Odontostilbe pulchra, against O. splendida.

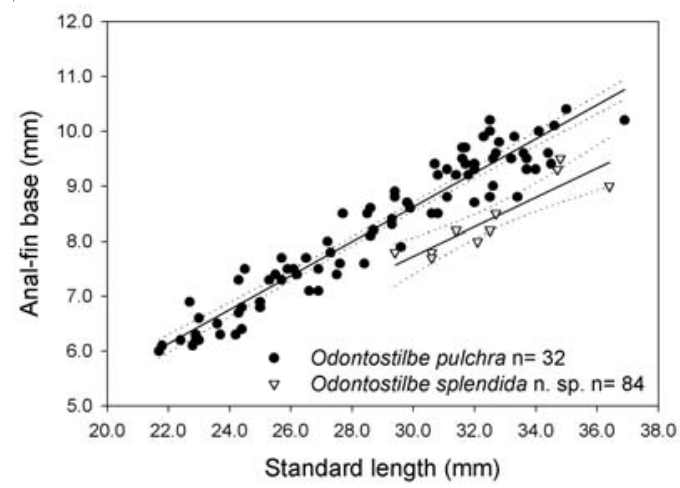

Fig. 14. Anal-fin base as a function of standard length for males of Odontostilbe pulchra, against $O$. splendida.

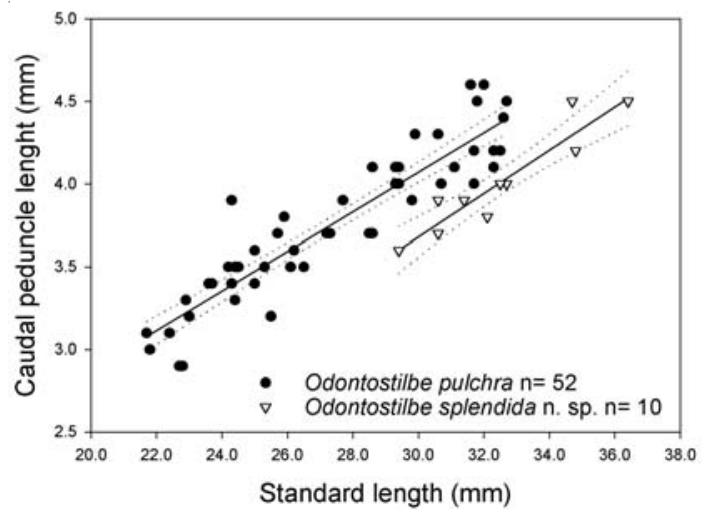

Fig. 15. Caudal peduncle length as a function of standard length for males of Odontostilbe pulchra, against O. splendida. rays longest. Pectoral-fin rays i(31), 9(2), 10(9), 11(16), or 12(3). Pelvic-fin rays i(31), 6(1), or 7(30). Unbranched pelvic-fin ray longest ray in mature males, extending beyond origin of anal fin. Lateral skin border of unbranched pectoral-fin ray and unbranched pelvic-fin ray slight thickened in males. Principal caudal-fin rays 19(31). Procurrent caudal-fin rays: dorsal 10(1),

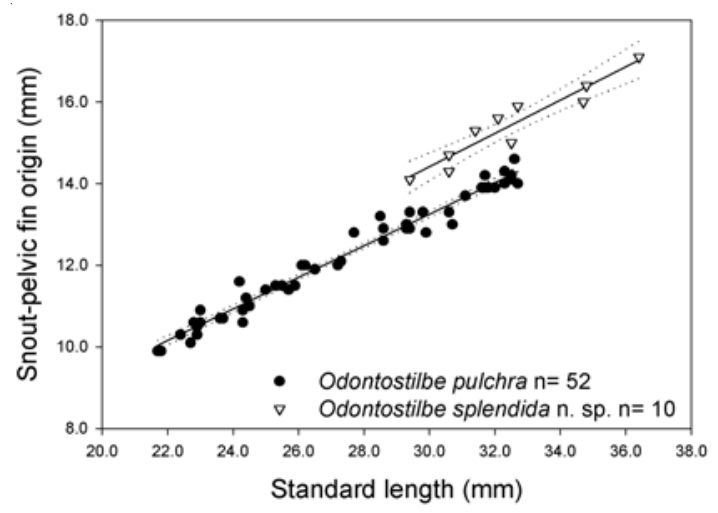

Fig. 16. Snout-pelvic fin origin as a function of standard length for males of Odontostilbe pulchra, against $O$. splendida.

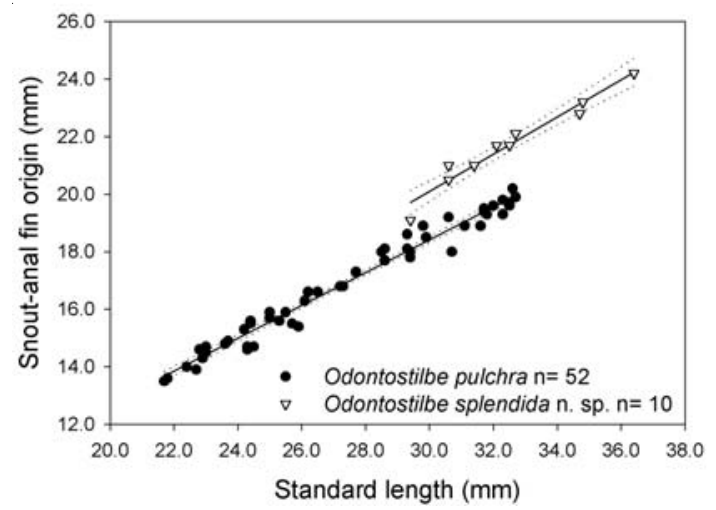

Fig. 17. Snout-anal fin origin as a function of standard length for males of Odontostilbe pulchra, against O. splendida.

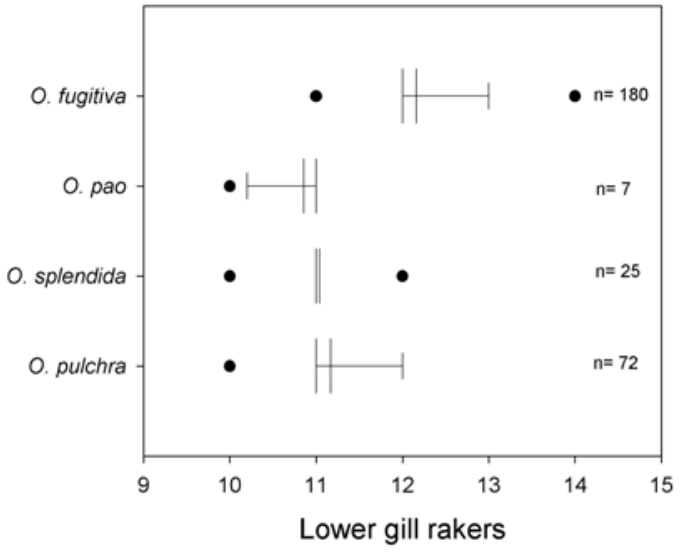

Fig. 18. Lower gill rakers counts of Odontostilbe pulchra, Odontostilbe fugitiva (data from Bührnheim \& Malabarba, 2006), and of two new species Odontostilbe splendida, and Odontostilbe pao. 


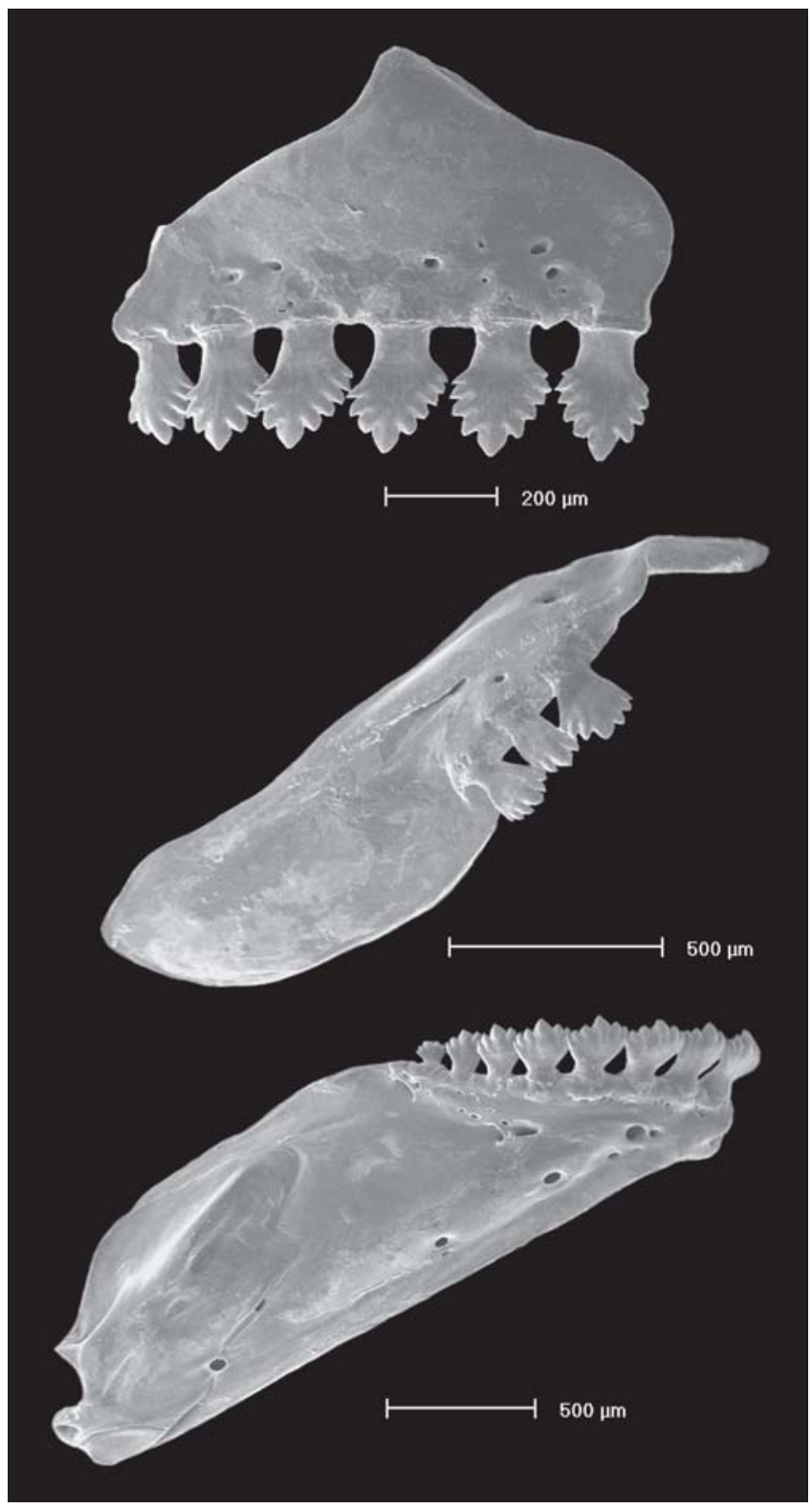

Fig. 19. Dentition of Odontostilbe splendida, paratype ANSP 181041, female $32.1 \mathrm{~mm} \mathrm{SL}$ : right side premaxilla (top), maxilla (middle), and dentary (bottom), lateral view. Scanning electron micrographs (SEM).

11(4), 12(14), 13(9), or 14(3), ventral 9(3), 10(17), 11(10), or 12(1). Anterior 1 or 2 ventral procurrent caudal-fin rays sometimes laterally expanded or bifurcated. Caudal-fin ray flaps ventrally on $4^{\text {th }}-8^{\text {th }}$ branched rays of upper lobe, dorsally on $13^{\text {th }}-16^{\text {th }}$ branched rays of lower lobe. Adipose-fin at vertical through last $2^{\text {nd }}$ or $3^{\text {rd }}$ anal-fin ray insertions.

Males with acute retrorse hooks on posterior border of pelvic- and anal-fin rays. One or two paired or unpaired hooks per segment of lepidotrichia, at distal half-length of last unbranched anal-fin ray, and $1^{\text {st }}$ to $6^{\text {th }}-7^{\text {th }}$ branched anal-fin rays. One or two unpaired long hooks per segment of lepidotrichia along almost entire length of $1^{\text {st }}$ to $7^{\text {th }}$ branched pelvic-fin rays, reaching distal tip of fin ray (except on $1^{\text {st }}$ branched pelvic-fin ray, on midlength
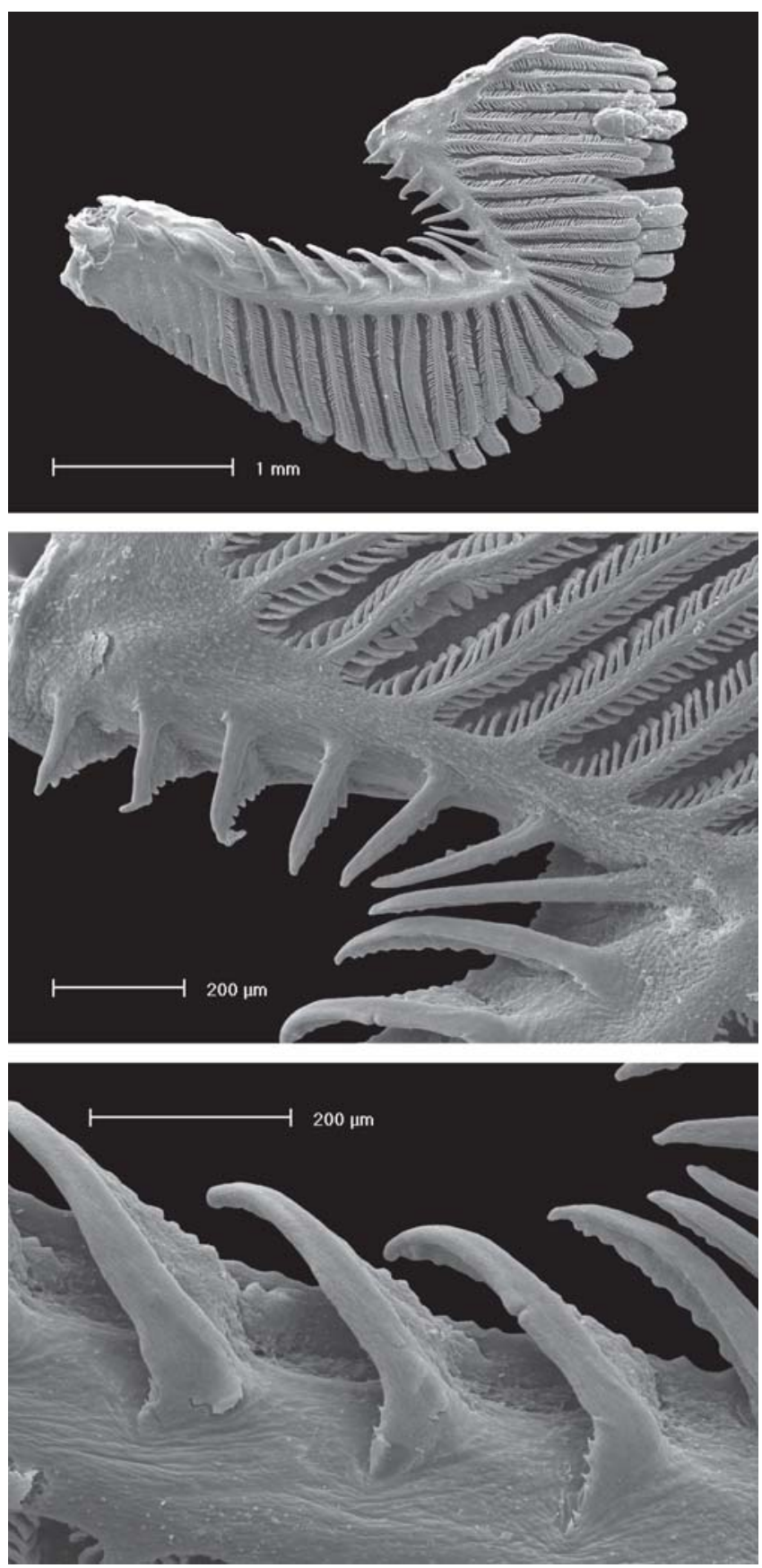

Fig. 20. First gill arch of Odontostilbe splendida, MCP 38862 , male $29.7 \mathrm{~mm}$ SL: left side, lateral view, showing gill gland (top), in detail gill rakers on upper branchial branch (middle), and gill rakers on lower branchial branch (bottom). Scanning electron micrographs (SEM).

portion). One or two unpaired hooks per segment of lepidotrichia on anterior border of branchings of pelvic- and anal-fin rays.

Scales cycloid: lateral line complete 35(1), or 36(26); predorsal row 10(10), or 11(20); scale rows between lateral line and dorsalfin origin 6(28), or 7(2); scale rows between lateral line and analfin origin 4(15), or 5(15); scale rows around caudal peduncle 14(29). Triangular modified scale on pelvic-fin base extends posterior covering 2-3 scales. Scales on anal-fin base 6 or 7 . 
Cleared and stained specimens (3), and radiographs (8): supraneurals 4; precaudal vertebrae, including Weberian apparatus, 16(3), or 17(8); caudal vertebrae 17(3), 18(7), or 19(1); gill rakers, upper 5(1), or 6(2), lower 10, 11, or 12 (2-3 on hypobranchial). Alcohol specimens (22): gill rakers, upper 5(2), 6(18), or 7(2), lower 11(21), or 12(1). Upper gill rakers with none to 3 denticles on anterolateral border; lower gill rakers with 1-4 recurved denticles on anterolateral border; and posteriormost lower gill raker with none to 7 recurved denticles on posterior border, and 3 denticles on anterior border (Fig. 20). Denticulation mainly on basal portion of gill rakers.

Color in alcohol. General ground body color pale yellow or pale orange. Dorsal part of body darker with chromatophores more concentrate on scales border, from head to caudal peduncle. Dark chromatophores along all dorsal-fin rays. Pectoral fin with chromatophores along $1^{\text {st }}$ unbranched pectoralfin ray and $1^{\text {st }}$ branched fin rays. Pelvic fin clear. Anal fin with dark chromatophores on central branched anal-fin rays, except at tips of last unbranched fin rays and $1^{\text {st }}$ branched fin ray; hyaline in holotype. Adipose fin clear. Caudal fin almost entirely covered with diffuse dark chromatophores along fin rays, except clear areas on base of caudal-fin lobes just behind caudal-fin spot (chromatophores very faded in type material). Rounded brown to black spot on base of caudal fin, usually reaching upper border of caudal peduncle.

Dark chromatophores on snout, upper lip, anteriormost portion of maxilla, and $1^{\text {st }}$ to $2^{\text {nd }}$ infraorbitals. Top of head on frontals and parietals pigmented, deep-lying dark chromatophores over brain membranes below frontals and parietals, and fontanels. Body with faint dark and silver midlateral stripe, beginning behind pseudotympanum, above lateral line, and reaching caudal spot. Guanine on eye iris, opercle, isthmus, and $2^{\text {nd }}$ to $5^{\text {th }}$ infraorbital. Presence or not of scattered chromatophores on pseudotympanum area. Below lateral line, belly faint usually unpigmented, chromatophores above anal-fin

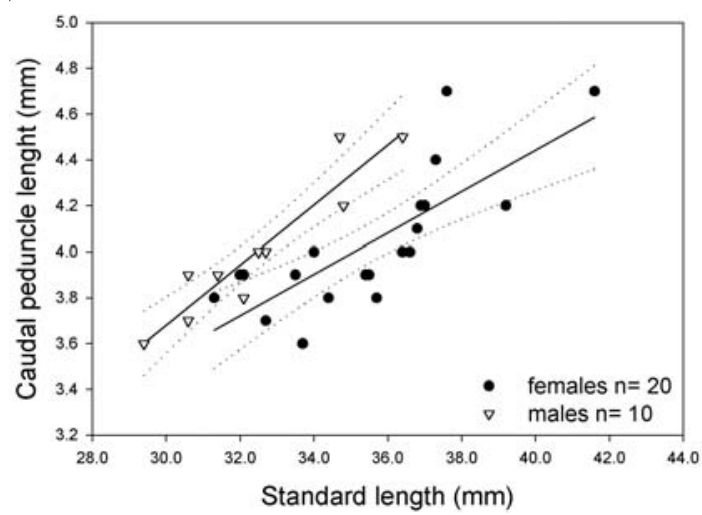

Fig. 21. Caudal peduncle length as a function of standard length for males against females of Odontostilbe splendida.

base area forming 10 to 11 chevron shaped markings (faint scattered chromatophores in type material).

Sexual dimorphism. Males have hooks on anal and pelvicfin rays, and slight elongation of dorsal- and pelvic-fin rays, in contrast to the absence of these features in females (see description). A gill gland (Burns \& Weitzman, 1996) is found in mature males of Odontostilbe splendida. The gill gland is present on the first gill arch, including about 7 to 9 anterior branchial filaments (Fig. 20). Males usually have longer snout length, and caudal peduncle length (Fig. 21).

Distribution. Río Orinoco basin (Fig. 22).

Etymology. Refers to the Latin word splendidus, meaning splendid, grand, admirable.

Ecological notes. Field notes of type material indicate bottom with mud and sand, and water depth nearly 3 feet.

Table 2. Morphometrics of Odontostilbe splendida (holotype ANSP 181040, and paratypes ANSP 181041).

\begin{tabular}{|c|c|c|c|c|c|c|c|c|c|}
\hline & \multicolumn{5}{|c|}{ Males } & \multicolumn{4}{|c|}{ Females } \\
\hline & Holotype & $\mathrm{n}$ & Low & High & Mean & $\mathrm{n}$ & Low & High & Mean \\
\hline Standard length $(\mathrm{mm})$ & 32.7 & 9 & 29.4 & 36.4 & 32.3 & 21 & 31.3 & 41.6 & 35.4 \\
\hline \multicolumn{10}{|c|}{ Percents of standard length } \\
\hline Head length & 25.4 & 9 & 23.1 & 25.8 & 24.5 & 21 & 22.2 & 24.6 & 23.5 \\
\hline Snout-anal fin origin & 67.6 & 9 & 63.7 & 68.6 & 66.5 & 21 & 66.5 & 70.9 & 69.1 \\
\hline Snout-dorsal fin origin & 51.1 & 9 & 47.5 & 51.6 & 49.8 & 21 & 49.2 & 52.9 & 51.8 \\
\hline Snout-pelvic fin origin & 48.6 & 9 & 45.1 & 48.7 & 47.3 & 21 & 46.6 & 50.8 & 48.9 \\
\hline Dorsal-fin base & 15.3 & 9 & 13.8 & 15.3 & 14.5 & 21 & 13.4 & 15.5 & 14.6 \\
\hline Anal-fin base & 26.0 & 9 & 24.9 & 26.8 & 25.8 & 21 & 24.0 & 28.3 & 26.4 \\
\hline Caudal peduncle length & 12.2 & 9 & 11.5 & 13.0 & 12.3 & 21 & 10.6 & 13.1 & 11.5 \\
\hline Caudal peduncle depth & 13.5 & 9 & 11.4 & 13.5 & 12.4 & 21 & 11.0 & 13.6 & 12.6 \\
\hline Depth at dorsal-fin origin & 36.1 & 9 & 33.5 & 37.1 & 35.5 & 21 & 36.5 & 42.6 & 39.9 \\
\hline Dorsal-fin length & 33.9 & 8 & 29.6 & 33.9 & 31.7 & 21 & 26.2 & 31.9 & 29.9 \\
\hline Pelvi & 20.2 & 9 & 19.0 & 22.1 & 20.3 & 21 & 16.3 & 19.4 & 17.9 \\
\hline Pectoral-fin length & 22.6 & 9 & 20.9 & 23.5 & 22.3 & 21 & 19.0 & 22.9 & 21.2 \\
\hline Snout-pectoral-fin origin & 24.5 & 9 & 21.7 & 25.2 & 23.6 & 21 & 21.4 & 24.6 & 23.1 \\
\hline \multicolumn{10}{|c|}{ Percents of head length } \\
\hline Snout length & 25.3 & 9 & 24.1 & 26.9 & 25.2 & 21 & 21.4 & 25.6 & 23.7 \\
\hline Upper jaw length & 30.1 & 9 & 29.1 & 31.5 & 30.3 & 20 & 28.4 & 32.6 & 30.8 \\
\hline Horizontal eye diameter & 38.6 & 9 & 36.0 & 39.0 & 37.6 & 21 & 36.8 & 41.0 & 38.4 \\
\hline Least interorbital width & 36.1 & 9 & 33.3 & 36.1 & 35.1 & 21 & 32.1 & 39.1 & 36.3 \\
\hline
\end{tabular}




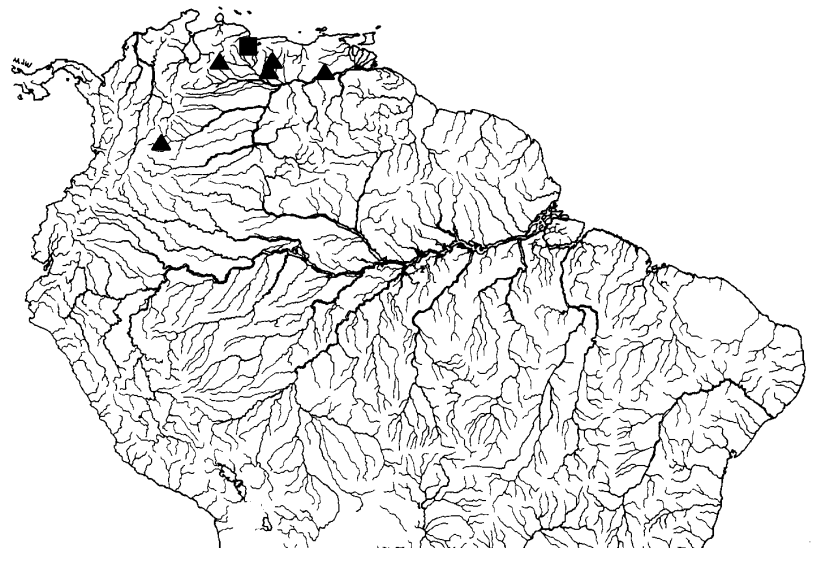

Fig. 22. Distribution of Odontostilbe splendida (triangles), and Odontostilbe pao (square). Symbols can represent more than one lot, and more than one locality.

\section{Odontostilbe pao, new species} Fig. 23

Holotype. MCNG 54497, 1 (male 29.3 mm SL), Venezuela, Cojedes, río Pao at el Caserio, El Pueblito, D. Taphorn et al., 28 July 1985.

Paratypes. MCNG 54107 (4 males 27.2-28.5 mm SL); MCP 40976 (1 male $28.7 \mathrm{~mm} \mathrm{SL}, 1$ male $28.8 \mathrm{~mm} \mathrm{SL}$ ), same data as the holotype.

Diagnosis. Odontostilbe pao differs from the two other species from the río Orinoco basin, by the presence of a remarkable elongation of the $2^{\text {nd }}$ unbranched dorsal-fin ray in males, not found in males of $O$. pulchra (Fig. 1), and short in males of $O$. splendida. Additionally, males of $O$. pao are distinguished from the two other Orinoco species by the longer snout length (O. pao 26.7-30.6\% HL, O. pulchra 18.0-26.0\% HL, O. splendida 24.1-26.9\% HL) (Figs. 5, 26), and longer upper jaw length (O. pao 32.5-34.7\% HL, O. pulchra 27.1-31.8\% HL, $O$. splendida 29.1-31.5\% HL) (Fig. 26). The presence of hooks on $1^{\text {st }}$ to $8^{\text {th }}$ anal-fin branched rays separates $O$. pao from $O$. pulchra (hooks on $1^{\text {st }}$ to $22^{\text {th }}$ anal-fin branched rays). The gill raker counts on lower branch (averaging 11) differ from $O$. fugitiva (usually 12) (Fig. 18). Odontostilbe pao differs from all other Odontostilbe species by the peculiar shape of the posterior portion of the maxilla, somewhat triangular, short, with midlength portion deeper and gradually narrowing to the posterior tip (Fig. 24), vs maxilla somewhat spatula-like shaped, short or elongate, with a deep midlength and posterior region, and then narrowing abruptly only at posterior tip in all other Odontostilbe species (Figs. 6, 19).

Description. Only males available. Morphometric data are given in Table 3. Largest male reaching $29.3 \mathrm{~mm}$ in SL. Body elongated and compressed. Greatest body depth at dorsalfin origin. Snout pointed. Head profile gently convex to straight from snout to posterior tip of supraoccipital bone. Predorsal profile slightly convex between tip of supraoccipital bone and dorsal-fin origin, then straight from dorsal-fin origin to caudal peduncle. Ventral profile convex from mouth to anal-fin origin. Anal-fin base straight. Caudal peduncle slightly longer than deep.

Head relatively small. Posterior margin of opercle sinusoidal with upper portion concave and lower portion convex. Snout pointed. Mouth terminal, premaxilla projects beyond dentary leaving border of teeth cusps exposed. Maxilla obliquely positioned ending at vertical on anterior eye border, and at horizontal slightly below inferior eye border. Premaxillary teeth 6, bearing 8-10 cusps; central cusp longest (Fig. 24). Maxilla with 4 similar teeth bearing 3-7 cusps, decreasing cusp number to posterior tip of maxilla. Dentary teeth 11 bearing 1-7 cusps, gradually decreasing in size, first 7 teeth largest with 6-7 cusps, 1 medium-sized tooth with 5 cusps, and last small teeth conical or with 2 cusps. Smaller cusps of dentary teeth overlap cusps of adjacent tooth.

Dorsal-fin rays ii,9(7). Dorsal fin slightly behind mid length of body, and slightly posterior to pelvic-fin origin. Second unbranched dorsal-fin ray elongate in males, extending beyond dorsal-fin distal profile. Anal-fin rays iv(1), v(6), 18(1),

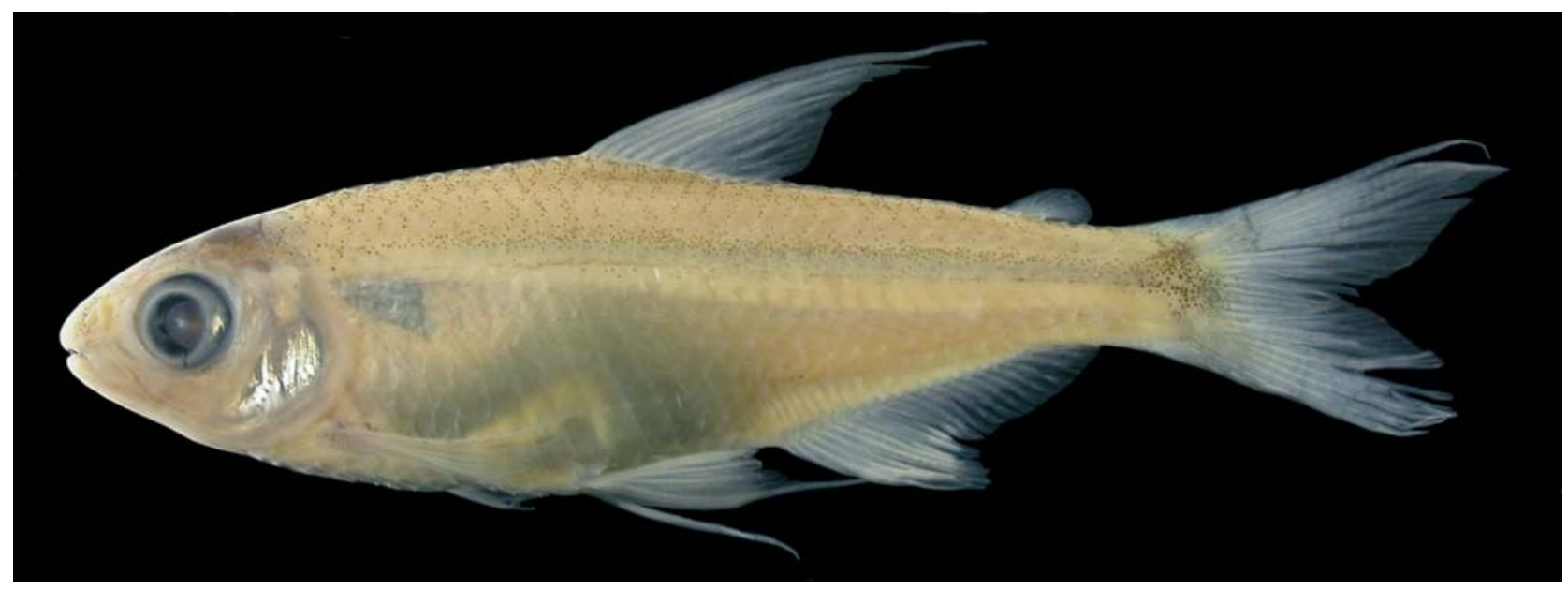

Fig. 23. Holotype of Odontostilbe pao, MCNG 54497, male $29.3 \mathrm{~mm}$ SL. 


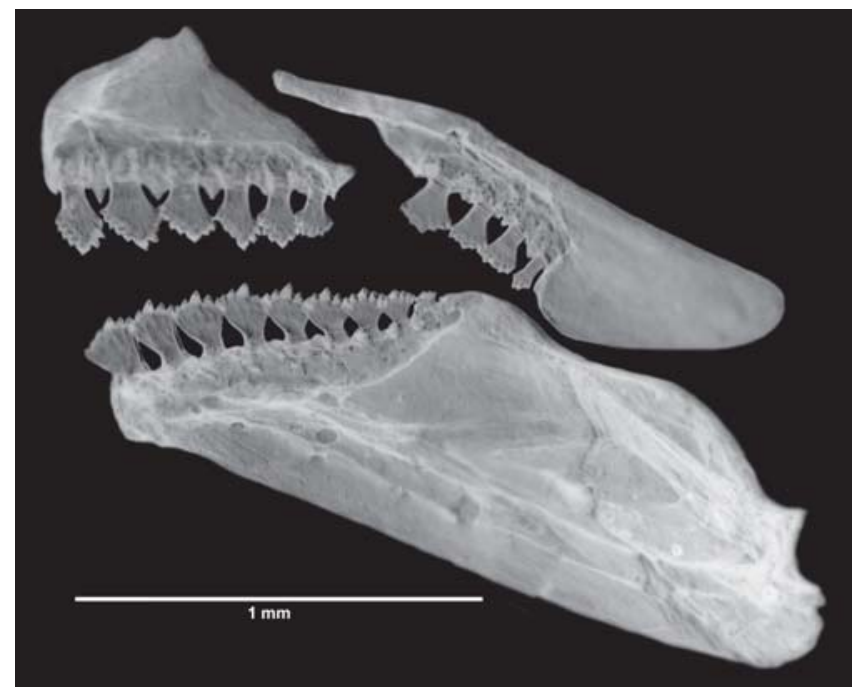

Fig. 24. Dentition of Odontostilbe pao, MCNG 54107, male $28.8 \mathrm{~mm}$ SL c\&s. Photograph of left side premaxilla (top), maxilla (middle), and dentary (bottom), lateral view, under estereosmicroscope.

19(2), or 20(4). Anal-fin distal border concave. Pectoral-fin rays $i(7), \mathbf{1 0}(2), 11(4)$, or 12(1). Pelvic-fin rays $\mathbf{i}(7), \mathbf{6 i}(2), 7(5)$. Unbranched pelvic-fin ray longest in mature males, extending beyond origin of anal fin. Lateral skin border of unbranched pectoral-fin ray and unbranched pelvic-fin ray slightly thickened in males. Principal caudal-fin rays 19(7). Procurrent caudal-fin rays: dorsal 11(3), or 12(4), ventral 9(1), 10(4), or 11(2). Caudal-fin ray flaps ventrally on $4^{\text {th }} 7^{\text {th }}$ branched rays of upper lobe, and dorsally on $13^{\text {th }}-15^{\text {th }}$ branched rays of lower lobe. Adipose-fin at vertical through last anal-fin ray insertion.

Males with acute, elongate, retrorse hooks on posterior border of pelvic- and anal-fin rays. One or two paired and unpaired hooks per segment on last unbranched anal-fin ray, and $1^{\text {st }}$ to $8^{\text {th }}$ (mostly $6-7^{\text {th }}$ ) anal-fin branched rays, mid positioned on fin rays. One or two unpaired slender hooks per segment on $1^{\text {st }}$ to $7^{\text {th }}$ branched pelvic-fin rays, extending almost entirely and reaching end tip of fin rays.

Scales cycloid: lateral line complete about 36 (scale insertions counted when scale is lacking); predorsal row 10(1), or 11(2); scale rows between lateral line and dorsal-fin origin 6(6), or 7(1); scale rows between lateral line and anal-fin origin 4(4); scale rows around peduncle missing. Triangular modified scale on pelvic-fin base extends posterior covering 2 scales.

Cleared and stained specimens (1): supraneurals 4; precaudal vertebrae, including Weberian apparatus, 16; caudal vertebrae 18; gill rakers, upper 6, lower 11 (2 on hypobranchial). Alcohol specimens (6): gill rakers, upper 6 (6), lower $10(1)$, or 11(5). Upper gill rakers with none to 2 denticles on anterolateral border, and none on posterolateral border; lower gill rakers with none or 2 denticles on anterolateral border, and none or 1 denticle on posterolateral border; posteriormost lower gill raker with just 3 denticles on anterolateral border (Fig. 25). Denticulation mainly on basal portion of gill rakers.
Sexual dimorphism. Only mature males available, presenting typical dimorphic characters found in other Odontostilbe species, like the presence of hooks on pelvic- and anal-fin rays, and the elongation of dorsal- and pelvic-fin rays. The gill gland is present on the first gill arch including 7 to 9 anterior branchial filaments (Fig. 25). Snout well-developed in males, and probably a dimorphic character as found in other Odontostilbe species (Bührnheim \& Malabarba, 2006).
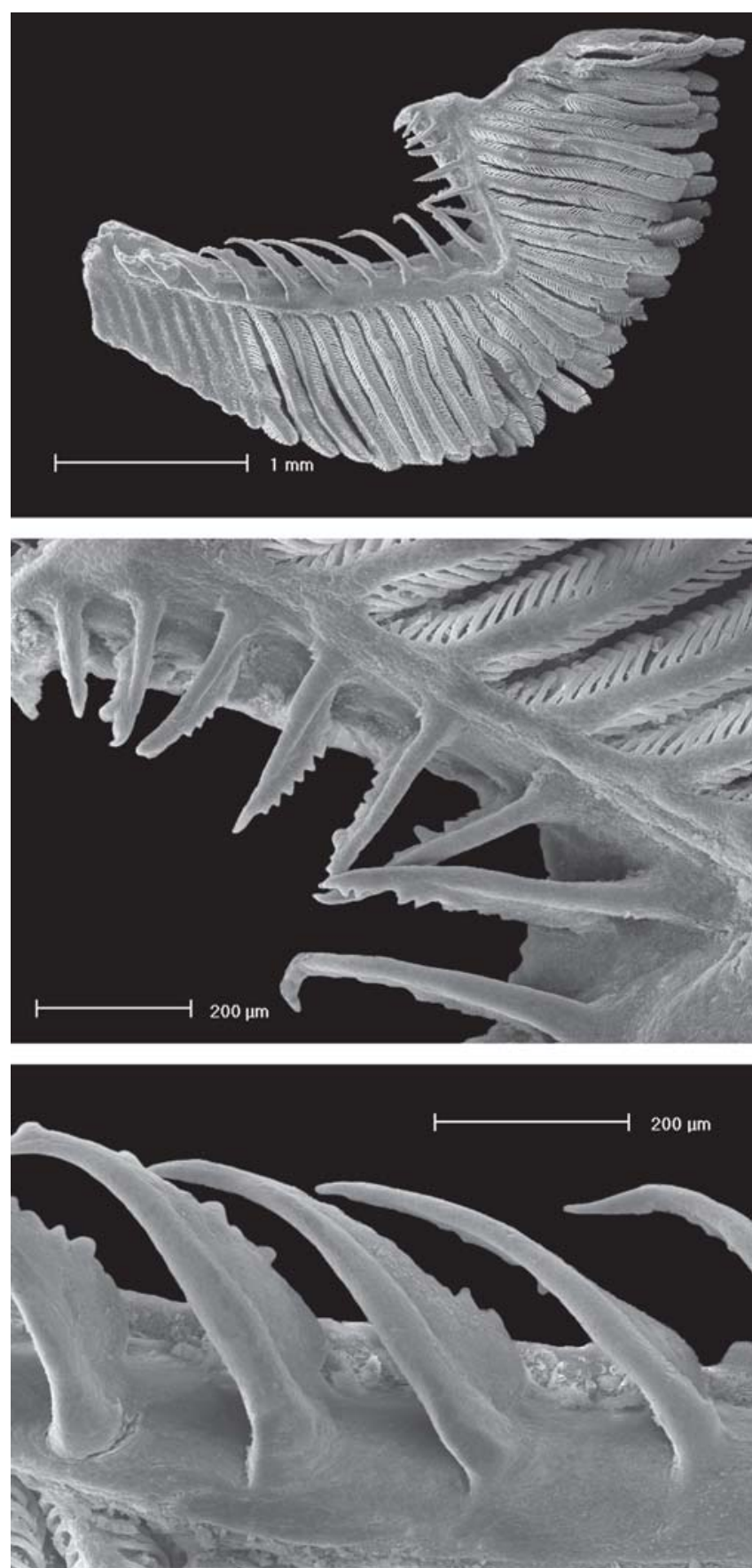

Fig. 25. First gill arch of Odontostilbe pao, MCNG 54107, male $28.8 \mathrm{~mm}$ SL. SEM photographs of the first gill arch, left side, lateral view, showing gill gland (top), in detail gill rakers on upper branchial branch (middle), and gill rakers on lower branchial branch (bottom). 
Color in alcohol. General ground body color beige. Dorsal part of the body from head to peduncle darker with chromatophores more concentrate on scales border. Dark chromatophores along all dorsal-fin rays. Pectoral fin with chromatophores along $1^{\text {st }}$ unbranched pectoral-fin ray and $1^{\text {st }}$ branched fin rays. Pelvic fin hyaline. Anal fin with dark chromatophores on more central branched anal-fin rays, except at the tips of the last unbranched fin rays and the $1^{\text {st }}$ branched fin ray; hyaline in holotype. Adipose fin clear. Caudal fin almost entirely covered with diffuse chromatophores along fin rays, except clearer areas on base of caudal-fin lobes just behind caudal-fin spot (chromatophores very faded in type material). Rounded black to brown spot on the base of caudal fin, reaching upper border of caudal peduncle.

Chromatophores on snout, upper lip, proximal portion of maxilla, infraorbitals 1, 2. Pigmentation of top of head on frontals and parietals, with deep-lying chromatophores over brain membrane below frontals and parietals, and fontanels. Faint dark and silver midlateral stripe, beginning behind pseudotympanum, above lateral line, and reaching caudal spot. Guanine on eye iris, opercle, isthmus, and most of $3^{\text {rd }}$ infraorbital. Below lateral line body faint without pigmentation, a few chromatophores above anal-fin base in holotype.

Distribution. Only known from type locality río Pao, affluent of the río Chirgua-Guanare system, río Portuguesa, río ApureOrinoco basin (Fig. 22).

Etymology. Refers to the type locality río Pao.
Table 3. Morphometrics of Odontostilbe pao (holotype MCNG 54497, and paratypes MCNG 54107).

\begin{tabular}{lccccc}
\hline & \multicolumn{5}{c}{ Males } \\
& Holotype & $\mathrm{n}$ & Low & High & Mean \\
\hline Standard length (mm) & 29.3 & 6 & 27.2 & 28.8 & 28.2 \\
& Percentages of standard length \\
Head length & 26.3 & 6 & 25.9 & 26.8 & 26.3 \\
Snout-anal fin origin & 63.8 & 6 & 63.3 & 66.3 & 64.7 \\
Snout-dorsal fin origin & 48.1 & 6 & 48.2 & 50.5 & 49.5 \\
Snout-pelvic fin origin & 46.8 & 6 & 47.1 & 48.9 & 48.2 \\
Dorsal-fin base & 15.0 & 6 & 14.1 & 16.0 & 14.8 \\
Anal-fin base & 24.6 & 6 & 25.4 & 27.1 & 26.3 \\
Caudal peduncle length & 14.0 & 6 & 12.5 & 13.3 & 13.0 \\
Caudal peduncle depth & 10.9 & 6 & 10.4 & 11.4 & 11.1 \\
Depth at dorsal-fin origin & 30.4 & 6 & 30.2 & 32.1 & 31.1 \\
Dorsal-fin length & 37.5 & 6 & 36.5 & 42.6 & 40.1 \\
Pelvic-fin length & 25.9 & 6 & 24.1 & 28.3 & 25.9 \\
Pectoral-fin length & 24.2 & 6 & 23.6 & 25.8 & 24.6 \\
Snout-pectoral-fin origin & 25.9 & 6 & 25.2 & 27.0 & 26.3 \\
& Percentages of head length & & & \\
Snout length & 28.6 & 6 & 26.7 & 30.6 & 28.6 \\
Upper jaw length & 33.8 & 6 & 32.5 & 34.7 & 33.5 \\
Horizontal eye diameter & 33.8 & 6 & 36.0 & 37.8 & 36.9 \\
Least interorbital width & 33.8 & 6 & 33.3 & 35.1 & 34.2 \\
\hline
\end{tabular}

Ecological notes. Type material was caught in the llanos, savannas, white water, together with the cheirodontines Cheirodontops geayi and Odontostilbe pulchra (Donald Taphorn pers. commun.).

Remarks. A principal component analysis with 17 morphometric variables grouped separately males of $O$. pao, O. splendida,

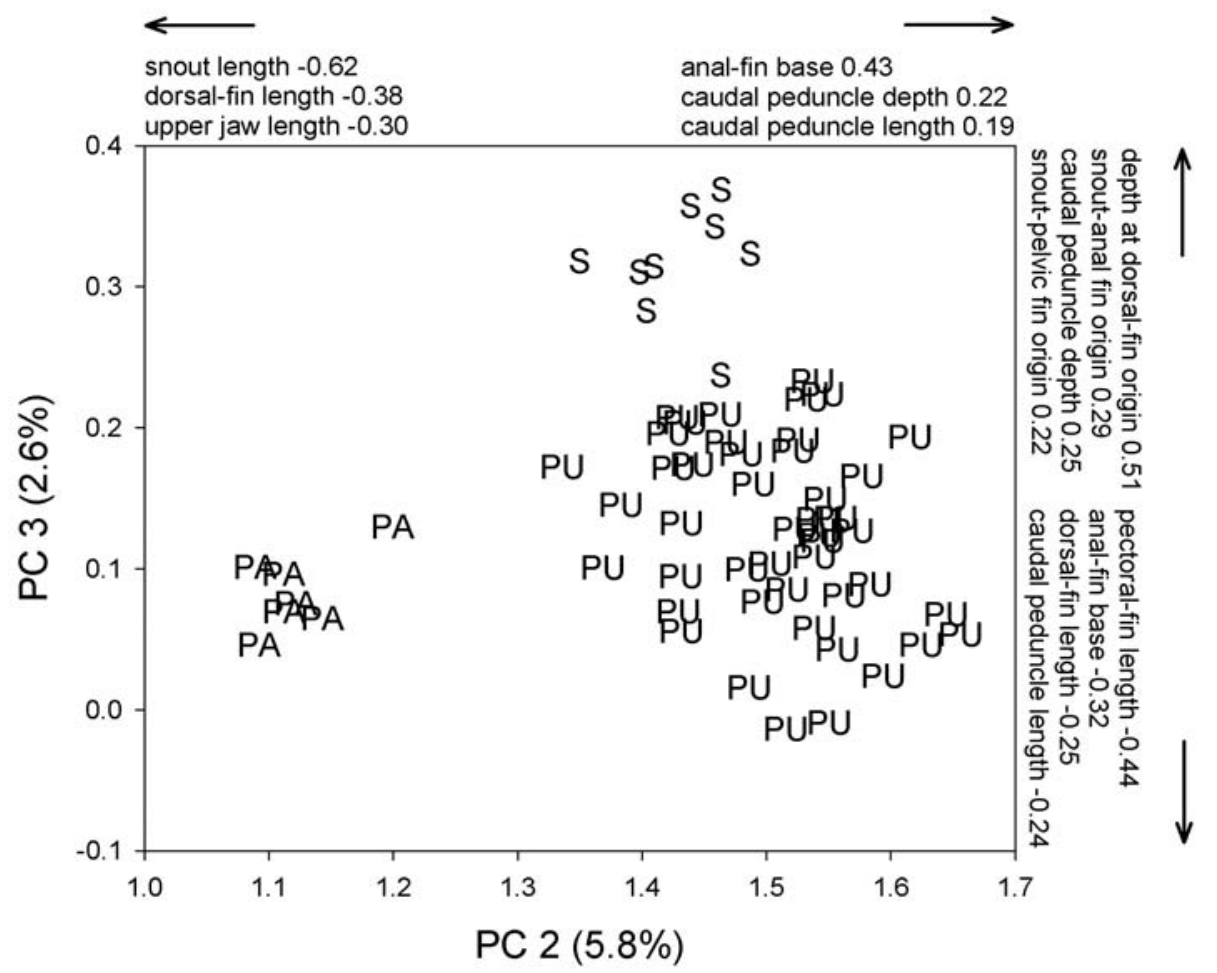

Fig. 26. Principal component analysis of the 17 morphometric measurements of males of Odontostilbe pulchra $(\mathrm{PU})$, Odontostilbe splendida (S), and Odontostilbe pao (PA). Stronger loadings on the second and third principal components (PC2, PC3). 
and $O$. pulchra, except for one specimen of $O$. splendida, nearby $O$. pulchra specimens on the PC3 axis (Fig. 26). PC2 was affected most strongly and negatively by snout length, dorsal-fin length, and upper jaw length; and positively by analfin base. Odontostilbe pao has longer snout length, dorsal-fin length, and upper jaw length as referred in its diagnosis. PC3 was affected most strongly and negatively by pectoral-fin length, and anal-fin base; and positively by depth at dorsal-fin origin, snout-anal fin origin, and caudal peduncle depth. Actually, O. pao and O. pulchra have smaller values for body depth at dorsal-fin origin, snout-anal fin origin, and caudal peduncle depth than $O$. splendida (Tables 1-3). In contrast, males of $O$. pao, and $O$. pulchra have longer pectoral-fin length, anal-fin base, and caudal peduncle depth (Tables 1-3). The specimen of $O$. splendida positioned far below has the highest proportion of anal-fin base $26.8 \%$ in SL among all specimens measured, which explains its position nearly $O$. pulchra specimens. This specimen through regression analyses matched $O$. splendida characters. The pelvic-fin length was not considered in the principal component analysis because it increased the overlap between $O$. pulchra and $O$. splendida since pelvicfin length ranges are similar.

\section{Discussion}

Böhlke (1954) suggested the synonym of Odontostilbe pulchra with $O$. fugitiva on the basis of a single specimen examined of the former, and four topotypes of the latter species. This hypothesis is refuted in the present study based on the diagnostic features we found to distinguish $O$. pulchra from $O$. fugitiva. Apparently without mature males available, Böhlke was not able to identify the remarkable differences in the anal fins of these species. Furthermore, he did not take measurements of the anal-fin base. The two species are the most widespread among all Odontostilbe species in northern South America, O. pulchra in Orinoco waters and $O$. fugitiva in Amazonian waters. The sole occurrence of $O$. pulchra in the rio Toototobi, rio Demini-upper rio Negro system, the major left-side affluent of rio Amazonas, open up a possible sympatry with $O$. fugitiva. However, neither $O$. pulchra nor O. fugitiva were assigned to the black water rio Negro, that might be a barrier since most Odontostilbe species seem to prefer whitewaters (Bührnheim \& Malabarba, 2006).

Odontostilbe pao was found possibly related to Pseudocheirodon terrabae and P. arnoldi, two Central American cheirodontines, forming the clade $\mathrm{A} 2$ in an overall parsimony analysis of the Cheirodontinae by Bührnheim \& Malabarba (in manuscript). However, this clade is discussed considering the weak support of that hypothesis versus the strong support of the recognition of a monophyletic clade including only Pseudocheirodon terrabae and P. arnoldi.

\section{Acknowledgements}

We thank the following persons for the loan of specimens: John Lundberg, Mark Sabaj, and Mike Littmann (ANSP), Jon Fong, David Catania, Tomio Iwamoto (CAS), Mary Ann Rogers, Mark Westneat, Barry Chernoff(FMNH), Mike Retzer (INHS), Iván Mojica (ICNMNH), Lúcia Py-Daniel, Leandro Souza, Maria Alrismar Brasil, Lindalva Serrão (INPA), Roberto Reis, Carlos Lucena, Margarete Lucena (MCP), Sonia Fisch-Müller, Claude Weber (MHNG), Donald Taphorn (MCNG), Patrice Pruvost, Guy Duhamel (MNHN), Richard Winterbottom, Erling Holm (ROM), Douglas Nelson (UMMZ), Stanley Weitzman, Richard Vari, Lisa Palmer, Sandra Raredon (USNM); Jorgen Nielsen (ZMUC). Special thanks to Cristina Cox Fernandes, John Lundberg during a visit to ANSP, and Stanley Weitzman for a visit to Smithsonian Institution (Tropical Fish Hobbyist fund). Thanks to Mônica Toledo-Piza, two anonymous referees, Tiago Carvalho and Mónica Rodriguez for the reviews. Specially to Donald Taphorn for the improvement of the manuscript. Rikke Pijnenburg and Christian Cramer checked Danish translation. Juliana Wingert and Tiago Salatino helped with MCP cataloguing. SEM photographs were taken at "Centro de Microscopia e Microanálises" - PUCRS.

\section{Literature Cited}

Alves, C. B. M. \& P. S. Pompeu (Eds.). 2001. Peixes do Rio das Velhas: passado e presente. Belo Horizonte, SEGRAC, 196p.

American Geographical Society of New York, 1957. Sheet NC 20 Boca del Orinoco. 1:1,000,000. Army Map Service, Corps of engineers.

Boeseman, M. 1960. The fresh-water fishes of the Island of Trinidad. Studies on the fauna of Curaçao and other Caribbean Islands, (48):73-153.

Böhlke, J. E. 1954. Studies on the phylogeny and systematics of fishes of the family Characidae. Doctoral Dissertation Series Publication no. 9477. Stanford University. University Microfilms, Ann Arbor, Michigan, 209p.

Britski, H. A. 2001. Sobre a obra Velhas-Flodens Fiske [Peixes do Rio das Velhas]. Cap. 1. Pp. 15-22. In: Alves, C. B. M. \& P. S. Pompeu (Eds.). Peixes do Rio das Velhas: passado e presente. Belo Horizonte, SEGRAC, 196p.

Bührnheim, C. M. \& L. R. Malabarba. 2006. Redescription of the type species of Odontostilbe Cope, 1870 (Teleostei: Characidae: Cheirodontinae), and description of three new species from the Amazon basin. Neotropical Ichthyology, 4(2): 167-196.

Dahl, W. H. 1916. Biographical Memoir of Theodore Nicholas Gill 1837-1914. National Academy of Sciences of the United States of America. Biographical Memoirs, part of volume VIII: 313-343.

Eigenmann, C. H. 1909. The fresh water fishes of Patagonia and an examination of the Archiplata-Archhelenis Theory. Reports of the Princeton University Expeditions to Patagonia, 1896-1899, 3(3): 225-374.

Eigenmann, C. H. 1910. Catalog of the freshwater fishes of Tropical south-temperate America. Reports of the Princeton University Expeditions to Patagonia, 1896-1899. Princeton University \& Stuttgart, 3(4): 375-511. 
Eigenmann, C. H. 1915. The Cheirodontinae, a subfamily of minute characid fishes of South America. Memoirs of the Carnegie Museum, 7(1): 1-99, pls. 1-17.

Eigenmann, C. H. 1920. The fishes of Lake Valencia, Caracas and of the Rio Tuy at Al Concejo, Venezuela. Indiana University Studies, 7(44): 1-13.

Eigenmann, C. H. \& R. S. Eigenmann, 1892. A catalogue of the fresh-water fishes of South America. Proceedings of the United States National Museum, 14: 1-81.

Fink, W. L. \& S. H. Weitzman. 1974. The so-called Cheirodontin fishes of Central America with descriptions of two new species (Pisces: Characidae). Smithsonian Contributions to Zoology, 172: 1-46.

Flecker, A. 1992. Fish trophic guilds and the structure of a tropical stream: weak direct vs. strong indirect effects. Ecology, 73(3): 927-940.

Fowler, H. W. 1943. Some Trinidad fresh-water fishes. The Fish Culturist, 22(9):65-67.

Gill, T. 1858. Synopsis of the fresh water fishes of the western portion of the Island of Trinidad, W. I. Annals of Lyceum of Natural History of New York, 6: 363-430.

Géry, J. 1977. Characoids of the world. T.F.H. Publications, Neptune City, 672p.

Günther, A. 1864. Catalogue of the fishes in the British Museum. Vol. 5, I-XII + 1-455p.

Guppy, P. L. 1934. Observations on Trinidad larvicidal fishes. Tropical Agriculture, II(5):117-122.

Hoeinghaus, D., K. O. Winemiller \& D. C. Taphorn. 2004. Composition change in fish assemblages along the Andean piedmont - Llanos foodplain gradinet of the río Portuguesa, Venezuela. Neotropical Ichthyology, 2(2): 85-92.

Hubert, N. \& J. Renno. 2006. Historical biogeography of South American freshwaters fishes. Journal of Biogeography: 1-23.

Jepsen, D. B. 1997. Fish species diversity in sand bank habitats of a neotropical river. Environmental Biology of Fishes, 49: 449-460.

Johnson, R. A. \& D. W. Wichern. 1998. Applied multivariate statistical analysis. $4^{\text {th }}$ ed. Prentice-Hall, New Jersey, 816p.

Lasso, C. A., A. Machado-Allison \& R. P. Hernández. 1990. Consideraciones zoogeograficas de los peces de la Gran Sabana (Alto Caroní), Venezuela, y sus relaciones con las cuencas vecinas. Memoria de La Sociedad de Ciencias Naturales La Salle, 133-134: 109-129.

Lasso, C. A., 1992. Composición y aspectos ecologicos de la ictiofauna del bajo río Apure, Serrania de Los Pijiguaos (Escudo Guayana), Venezuela, Memoria de la Fundación La Salle de Ciencias Naturales, LII(138): 5-56.

Lasso, C. A., D. Lew, D. C. Taphorn, C. Nascimiento, O. LassoAlcalá, F. Provenzano, A. Machado-Allison. 2003. Biodiversidad ictiológica continental de Venezuela. Parte I: Lista de especies y distribución por cuencas. Memoria de La Sociedad de Ciencias Naturales La Salle, 159-160: 105-195.

Lasso, C. A., J. I. Mojica, J. S. Usma, J. A. Maldonado-O., C. Nascimiento, D. C. Taphorn, F. Provenzano, Ó. M. LassoAlcalá1, G. Galvis, L. Vásquez, M. Lugo, A. Machado-Allison, R. Royero, C. Suárez y A. Ortega-Lara. 2004. Peces de la cuenca del río Orinoco. Parte I: lista de especies y distribución por subcuencas. Biota Colombiana 5(2): 95-158.

Lundberg, J.G., L.G. Marshall, J. Guerrero, B. Horton, M. C. Malabarba \& F. Wesselingh. 1998. The stage for neotropical fish diversification: a history of tropical South American rivers, Pp13-48. In: Malabarba, L. R, R. E. Reis, R. P. Vari, Z. M. S. Lucena \& C. A. S. Lucena (Eds.). Phylogeny and Classification of Neotropical Fishes. Porto Alegre, Edipucrs, 603p.
Lütken, C. 1875. Ichthyolographiske Bidrag. III. Nogle nye eller mindre fuldstændigt kjendte, mellem- eller sydamerikanske Karpelax (Characiner). Videnskabelige Meddelelsel fra den naturhistoriske Forening i Kjöbenhavn 1874, (12-16): 220-240.

Malabarba, L. R. 1998. Monophyly of the Cheirodontinae, characters and majors clades (Ostariophysi: Characidae). Pp. 193-233. In: Malabarba, L. R, R. E. Reis, R. P. Vari, Z. M. S. Lucena \& C. A. S. Lucena (Eds.). Phylogeny and Classification of Neotropical Fishes. Porto Alegre, Edipucrs, 603p.

Malabarba, L. R. 2003. Subfamily Cheirodontinae (Characins, tetras). Pp. 215-221. In: R. E. Reis; S. O. Kullander \& C. J. Ferraris (Eds.). Check list of the freshwater fishes of South and Central America. Porto Alegre, Edipucrs, 729p.

Malabarba, L. R. \& F. C. T., Lima \& S. H. Weitzman. 2004. A new species of Kolpotocheirodon (Teleostei: Characidae: Cheirodontinae: Compsurini) from Bahia, northeastern Brazil, with a new diagnosis of the genus. Proceedings of the Biological Society of Washington, 117(3): 317-329.

Malabarba, L. R. \& S. H. Weitzman. 1999. A new genus and species of South American fishes (Teleostei: Characidae: Cheirodontinae) with a derived caudal fin, including comments about inseminating cheirodontines. Proceedings of the Biological Society of Washington, 112(2): 410-432.

Nielsen, J. G. 1974. Fish types in the Zoological Museum of Copenhagen, $115 \mathrm{p}$.

Price, J. L. 1955. A survey of the freshwater fishes of the Island of Trinidad. Journal of the Agricultural Society of Trinidad \& Tobago.(Society Paper 863): 1-28.

Regan, C. T. 1906. On the fresh water fishes of the Island of Trinidad, based on the collections, notes, and sketches made by Mr. Lechmere Guppy, Junr. Proceeding of the Zoological Society of London, (1):378-393.

Schultz, L. P. 1944. The fishes of the family Characinidae from Venezuela, with descriptions of seventeen new forms. Proceedings of the United States National Museum, 95(3181): 235-267.

Strauss, R. E. 1985. Evolutionary allometry and variation in body form in the South American catfish genus Corydoras (Callichthyidae). Systematic Zoology, 34: 381-396.

Taphorn, D. C. 1992. The Characiforms fishes of the Apure River drainage, Venezuela. Biollania 4 (Edición Especial): 1-537.

Taphorn, D., R. Royero, A. Machado-Allison \& F. Mago-Leccia. 1997. Lista actualizada de los peces de agua dulce de Venezuela. Vertebrados Actuales y Fósiles de Venezuela. Pp. 55-100. In: La Marca, E. (Ed.). Serie Catálogo Zoológico de Venezuela, 1. Museo de Ciencia y Tecnología de Mérida, Venezuela, 275p.

Taylor, W. R. \& G. C. Van Dyke. 1985. Revised procedures for staining and clearing small fishes and other vertebrates for bone and cartilage study. Cybium, 9(2): 107-119.

Ulrey, A. B. 1895. The South American Characinidae collected by Charles Frederick Hartt. Annals of the New York Academy of Sciences, New York, 8:258-300.

Vari, R. P. \& J. C. Howe. 1991. Catalog of type specimens of recent fishes in the National Museum of Natural History, Smithsonian Institution, 1: Characiformes (Teleostei: Ostariophysi). Smithsonian Contributions to Zoology, 517: 1-52.

Winemiller, 1989. Ontogenetic diet shifts and resource partitioning among piscivorous fishes in the Venezuelan llanos. Environmental Biology of Fishes, 26: 177-199.

Winemiller, K. O. \& E. R. Pianka. 1990. Organization in natural assemblages of desert lizards and tropical fishes. Ecological Monographs, 60(1): 27-55. 